\title{
Molecular Phylogenies of Fig Wasps: Partial Cocladogenesis of Pollinators and Parasites
}

\author{
Carlos Lopez-Vaamonde,* Jean Yves Rasplus, † George D. Weiblen, $\ddagger$ and James M. Cook*,1 \\ * Department of Biology \& NERC Centre for Population Biology, Imperial College, Silw ood Park, Ascot, Berkshire SL5 7PY, \\ United Kingdom; †INRA, Centre de Biologie et de Gestion des Populations, Campus International de Baillarguet, \\ CS 30016, 34988 M ontferrier-sur-Lez, France; and ‡Department of Zoology, 203 Natural Science Building, \\ M ichigan State University, East Lansing, Michigan 48824
}

Received October 24, 2000; revised April 13, 2001

Figs (Ficus spp., Moraceae) and their pollinating wasps form an obligate mutualism, which has long been considered a classic case of coevolution and cospeciation. Figs are also exploited by several clades of nonpollinating wasps, which are parasites of the mutualism and whose patterns of speciation have received little attention. We used data from nuclear and mitochondrial DNA regions to estimate the phylogenies of $\mathbf{2 0}$ species of Pleistodontes pollinating wasps and 16 species of Sycoscapter nonpollinating wasps associated with Ficus species in the section Malvanthera. We compare the phylogenies of $\mathbf{1 5}$ matched Pleistodontes/Sycoscapter species pairs and show that the level of cospeciation is significantly greater than that expected by chance. Our estimates of the maximum level of cospeciation (50 to $64 \%$ of nodes) are very similar to those obtained in other recent studies of coevolved parasitic and mutualistic associations. However, we also show that there is not perfect congruence of pollinator and parasite phylogenies (for any substantial clade) and argue that host plant switching is likely to be less constrained for Sycoscapter parasites than for Pleistodontes pollinators. There is perfect correspondence between two terminal clades of two sister species in the respective phylogenies, and rates of molecular evolution in these pairs are similar. ๑ 2001 Academic Press

Key Words: Agaonidae; Pleistodontes; Sycoscapter; Ficus; fig wasps; Malvanthera; coevolution; cospeciation; 28S; ITS2; cytochrome b.

\section{INTRODUCTION}

The speciation of parasites is often thought to be driven by the speciation of their hosts, such that, when an ancestral host species splits into two daughter species, its parasite also speciates. This assumption un-

\footnotetext{
${ }^{1}$ To whom correspondence and reprint requests should be addressed. Fax (+44) 207594 2339. E-mail: j.cook@ic.ac.uk.
}

derpins the idea (Fahrenholz's rule) that host and parasite phylogenies should be mirror images (Lyal, 1986). Although cospeciation is not a new idea, the opportunity offered by molecular techniques to test it has led to a burst of interest and activity in this area (Hafner et al., 1994; Hafner and Page, 1995; Moran et al., 1995; Page, 1996a; Farrell and Mitter, 1998; Peek et al., 1998; Clark et al., 2000). Molecular markers may permit the estimation of phylogenies for parasites and their hosts by use of genes that (unlike some morphological traits) are not coadapted to the species interaction. Further, if cospeciation is inferred, molecular data can be used to compare rates of evolution in host and parasite lineages (Hafner and Nadler, 1990; Hafner et al., 1994; Hafner and Page, 1995; Moran et al., 1995; Page, 1996a; Paterson et al., 2000).

To date few cospeciation studies have produced molecular phylogenies for both sets of taxa and insights are limited to a few systems. One interaction in particular-that between pocket gophers (geomyid rodents) and their chewing lice - has dominated both methodological (Page, 1990, 1993a,b, 1994) and biological (Nadler et al., 1990; Demastes et al., 1998) debates about cospeciation. The pioneering studies based on allozyme (Hafner and Nadler, 1988) and DNA (Hafner et al., 1994) data provided evidence for a high degree of cospeciation in the gopher-louse assemblage. However, both studies are based on small phylogenies and may not be typical of mammals and lice, or other ectoparasites, in general (Taylor and Purvis, 2001). A recent study of pinworms and primates (Hugo, 1999) suggests that at least some endoparasites have undergone considerable cospeciation with their hosts. More predictably, high cospeciation levels have been inferred between invertebrates and endosymbiotic algae or bacteria that contribute significantly to host metabolism (Peek et al., 1998; Funk et al., 2000). Finally, whereas endogenous retroviruses generally track host phylogeny, occasional host shifts do occur, even between mammals and birds (Martin et al., 1999). 
Lice, endosymbiotic bacteria, retroviruses, and fig wasps are not expected to have the same levels of cospeciation as they encompass a range of interactions, with different transmission mechanisms. However, the same methods can be used to analyze these different systems, and, as case studies accumulate, it should become possible to identify general features of interactions (e.g., transmission mode) that promote or limit cospeciation (Clayton et al., 2001).

Phytophagous insects can be regarded as parasites of their host plants (Price, 1977) and may be generalists or specialists. Some specialists attack just a single plant species, whereas many others feed on a few closely related species. Interaction and coevolution have probably been important during the radiations of plant lineages and their insect herbivores, with plant chemistry playing a key role (Ehrlich and Raven 1964); however, strict sense cospeciation seems generally unlikely (Farrell and Mitter, 1990, 1998). More specific interactions occur between certain groups of plants and their pollinators and perhaps the two best-known cases are figs and fig wasps (Herre, 1996; Anstett et al., 1997) and yuccas and yucca moths (Pellmyr and Leebens-Mack, 1999). Both of these systems are mutualisms but also involve conflicts of interest, principally over whether female flowers nourish developing seeds or insect larvae.

Figs (Ficus spp.) and their pollinating wasps (family Agaonidae sensu Rasplus et al., 1998) provide a classic example of an obligate mutualism. Most Ficus species have their own unique pollinating wasp species, whose larvae feed on the fig seeds. Each partner relies on the other to complete its life cycle and many morphological characters of the partners are thought to be coadapted (Herre, 1989; Van Noort and Compton, 1996). The biology of figs and their pollinators has led to a general acceptance of the idea that they have coevolved and cospeciated extensively. However, rigorous testing of this idea has been hindered by the fact that the pollinator taxonomy has developed under the influence of existing fig taxonomy and a strong cospeciation assumption (Ramirez, 1974, 1977; Wiebes, 1982b).

Fig-based invertebrate communities lend themselves to cospeciation studies because, in addition to pollinating wasps, there are diverse nonpollinating wasps, mites, drosophilids (Harry et al., 1996), and parasitic nematodes (Poinar and Herre, 1991). Many (perhaps most) of these taxa are highly host-specific parasites of the figs or each other, suggesting that phylogenetic studies may identify key differences that are associated with cospeciation. Informative genes have been found for both pollinating (Herre et al., 1996; Machado et al., 1996, 2001; Kerdel hue et al., 1999) and nonpollinating (Machado et al., 1996; Rasplus et al., 1998) wasps but there has been less success with closely related Ficus species (Weiblen, 2000; C. LopezVaamonde et al., unpublished). Initial molecular phy- logenetic studies of Panamanian pollinating and associated nonpollinating wasps (Machado et al., 1996) and of figs and pollinators in general (Herre et al., 1996), were consistent with high levels of cospeciation.

Australasia harbors great Ficus diversity with at least 130 species in New Guinea al one (Wiebes, 1982a). The section Malvanthera Corner comprises 22 species, 14 of which are endemic to Australia and 8 to New Guinea (Corner, 1965). There are two distinct groups: a lineage of stranglers and free-standing trees found in rainforests of eastern Australia and New Guinea and a clade of lithophytic shrubs and trees found in more arid parts of Australia. Malvanthera species are all pollinated by wasps in the genus Pleistodontes and are exploited by a range of nonpollinating wasps (Boucek, 1988; Cook and Power, 1996), of which Sycoscapter species are the most prevalent. Sycoscapter larvae are thought to be either true parasitoids or phytophagous kleptoparasites of the pollinators (Boucek, 1993; Compton et al., 1994). Although both are referred to as fig wasps, Pleistodontes and Sycoscapter are distantly related genera from different families of chalcid wasps (Rasplus et al., 1998).

In this paper, we use nuclear and mitochondrial DNA sequences to infer phylogenies for 20 Pleistodontes and 16 Sycoscapter species from Malvanthera figs. We test two null hypotheses of host-parasite associations (Fig. 1; see Huelsenbeck et al., 1997, 2000; Clark et al., 2000). HI is that host and parasite phylogenies have been produced by independent random-branching processes. Acceptance of $\mathrm{HI}$ infers that cospeciation has been rare or absent, whereas rejection of $\mathrm{H} 1$ suggests that cospeciation (or another process imparting congruence) has occurred. In the latter case we can then test $\mathrm{H} 2$ that Pleistodontes and Sycoscapter data sets are consistent with the same underlying tree topology (Peek et al., 1998; Clark et al., 2000; Huelsenbeck et al., 2000, 2001; J ohnson et al., 2001). Acceptance of $\mathrm{H} 2$ would provide stronger evidence for strict cospeciation and permit a test of $\mathrm{H} 3$ that the rates of molecular evolution and speciation times are the same in the two clades.

\section{MATERIAL AND METHODS}

\section{Taxon Sampling}

In taxonomic terms, Malvanthera figs and their pollinators represent one of the best studied groups of figs and wasps. The Australian Malvanthera species have been revised recently with the description of five new species (Dixon, 2001a,b; Dixon et al., 2001). Meanwhile, we are currently revising the taxonomy of Pleistodontes pollinating wasps with the description of six new species (C. Lopez-Vaamonde et al., unpublished). The taxonomy of Sycoscapter (like most genera of nonpollinating fig wasps) is less advanced, with only two 


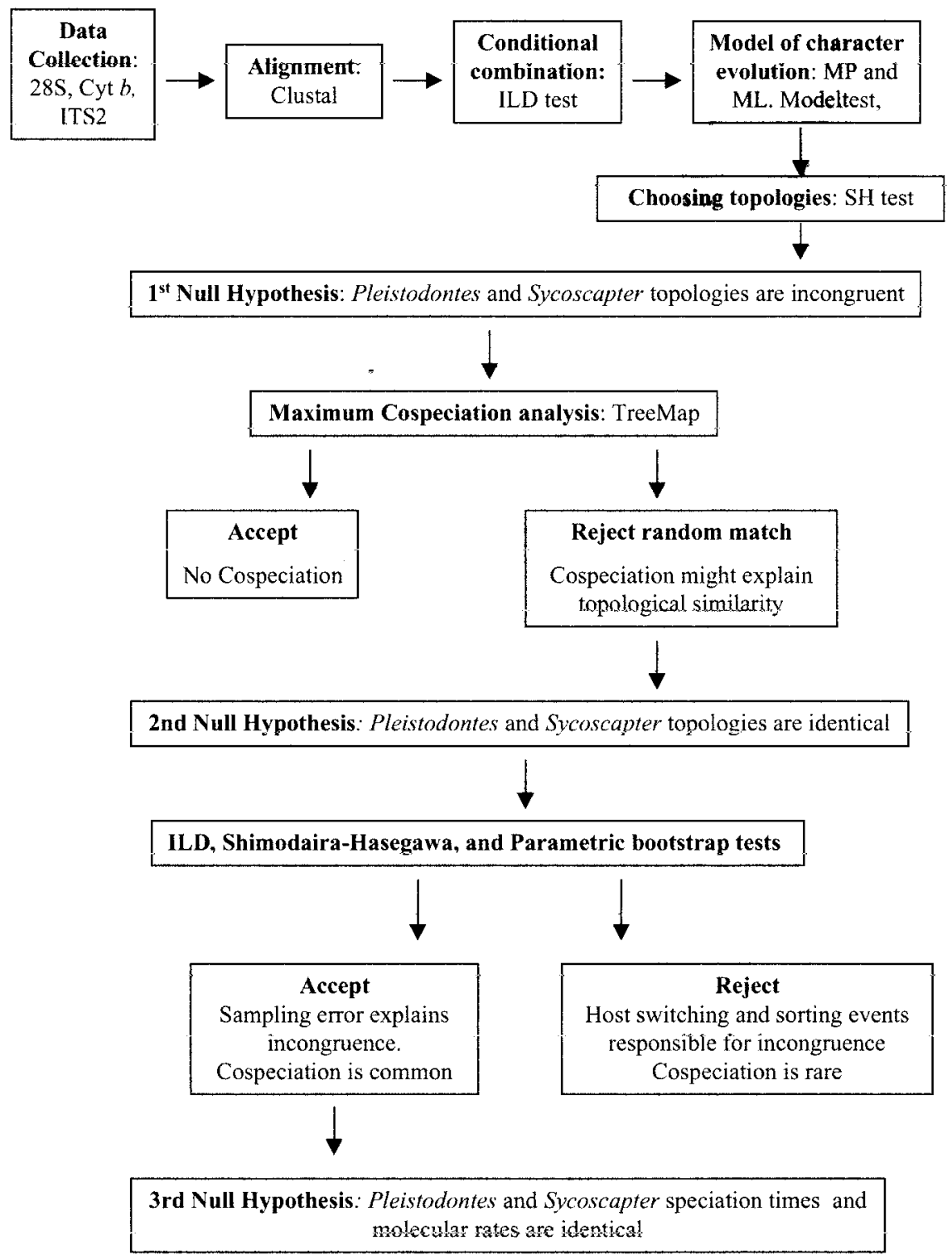

FIG. 1. Flow chart of data analysis procedures.

Malvanthera-feeding species described formally (Boucek, 1988). Sycoscapter wasp samples were collected from the same tree (and usually fruit) as the pollinators and were assigned to morphospecies.

Page (1996b) highlighted the importance of exhaustive phylogenetic sampling in host-parasite studies. We obtained specimens of Pleistodontes and Sycoscapter wasps from all but one Australian Malvanthera species and from three of the eight species from $\mathrm{New}$ Guinea (Table 1). Voucher wasp specimens are deposited at the Natural History Museum, London.

\section{Mol ecular Procedures}

We estimated phylogenies using data from three different genes: the mitochondrial cytochrome b (Cyt b), the nuclear $28 \mathrm{~S}$ rDNA (28S), and the internal transcribed spacer (ITS2) of the eukaryotic ribosomal DNA (rDNA) transcription unit. These regions all evolve at sufficiently high rates to provide phylogenetic information at lower taxonomic levels in the Hymenoptera (Stone and Cook, 1998; Kerdelhue et al., 1999). We sequenced a total of 1802 bp (length for aligned Cyt b, 285, and ITS2 sequence data) for Pleistodontes species and 1168 bp (Cyt b and 28S) for Sycoscapter species. We decided to sequence a third gene (ITS2) only for Pleistodontes. This was because, whereas Cyt $b$ and $28 \mathrm{~S}$ produced well-resolved Sycoscapter trees, the pollinator phylogenetic signal required further augmentation. 
TABLE 1

Specimens Used in This Study

\begin{tabular}{|c|c|c|c|c|c|}
\hline Species name & Host Ficus & Collection site & Code $^{a}$ & Coll $^{b}$ & Accession Nos. 28S/cyt b/lTS2 \\
\hline \multicolumn{6}{|l|}{ Family Agaonidae } \\
\hline Pleistodontes athysanus nom. provis & F. brachypoda nom. provis. & Western Australia & $357(470)$ & DD & AJ 275069/AJ 298423/AF 284589 \\
\hline Pleistodontes xanthocephal us nom. provis. & F. obliqua G. Forst & Cooktown, Queensland, Australia & 361 & $J M C$ & AJ 275070/AJ 298424/AF 284590 \\
\hline Pleistodontes cuneatus Wiebes, 1990 & F. platypoda (Miq.) & $\begin{array}{l}\text { Kununurra, Kimberley, Western } \\
\text { Australia }\end{array}$ & $362(455)$ & DD & AJ 275071/AJ 298425/AF 284587 \\
\hline Pleistodontes greenwoodi (Grandi, 1928) & F. obliqua G. Forst & Hayman Island, East coast of Australia & $363(188)$ & IGC & AJ 275072/AJ 298426/AF 284591 \\
\hline Pleistodontes macrocainus nom. provis. & F. cerasicarpa nom. provis. & Mount Isa, Australia & 365 (405) & DD & AJ 275073/AJ 298427/AF 284585 \\
\hline Pleistodontes proximus Wiebes, 1990 & F. lilliputiana nom. provis. & Lake Argyle, Western Australia & 367 (449) & DD & AJ $275074 / A J ~ 298428 / A F 284588$ \\
\hline Pleistodontes astrabocheilus nom. provis. & F. subpuberula Corner & $\begin{array}{l}\text { Kununurra, Twin Pools, Western } \\
\text { Australia }\end{array}$ & $369(442)$ & DD & AJ 275075/AJ 298429/AF 284586 \\
\hline Pleistodontes regalis Grandi, 1952 & F. pleurocarpa F. Muel. & $\begin{array}{l}\text { Mount Sorrow, Queensland, Eastern } \\
\text { Australia }\end{array}$ & 371 & CLV & AJ 275076/AJ 298430/AF 284601 \\
\hline Pleistodontes schizodontes nom. provis. & F. triradiata Corner & $\begin{array}{l}\text { Mount Windsor, Atherton Tablelands, } \\
\text { Australia, }\end{array}$ & $372(354)$ & DD & AJ 275077/-/AF 284592 \\
\hline Pleistodontes nitens (Girault, 1915) & F. crassipes F. M. Bailey & $\begin{array}{l}\text { Upper Cooper Creek, Queensland, } \\
\text { Australia }\end{array}$ & 374 & CLV & AJ 275078/AJ 298431/AF 284593 \\
\hline Pleistodontes blandus Wiebes, 1963 & F. glandifera Summerh. & $\begin{array}{l}\text { Keravat, East New Britain, Papua New } \\
\text { Guinea (CLV01) }\end{array}$ & 376 & CLV & AJ 275079/-/AF 284594 \\
\hline Pleistodontes spec. nov. 1 & Ficus sp. aff. xylosycia Diels & $\begin{array}{l}\text { Raunsepna, East New Britain, Papua } \\
\text { New Guinea (CL V10) }\end{array}$ & 378 & CLV & AJ 275080/AJ 298432/AF 284599 \\
\hline \multirow[t]{2}{*}{ Pleistodontes rieki Wiebes, 1963} & F. xylosycia Diels & $\begin{array}{l}\text { Ohu Conservation area, Madang, } \\
\text { Papua New Guinea }\end{array}$ & 427 & $\mathrm{BI}$ & AJ 275087/AJ 298433/AF 284597 \\
\hline & & $\begin{array}{l}\text { Raunsepna, East New Britain, Papua } \\
\text { New Guinea (CLV11) }\end{array}$ & 381 & CLV & AJ $275081 /-/-$ \\
\hline Pleistodontes near blandus & Unknown at light & Guadalcanal, Sol omon Islands, & $384 / 385$ & $J \mathrm{~L}$ & AJ 275082/AJ 298434/AF 284595 \\
\hline Pleistodontes rigisamos Wiebes, 1991 & F. destruens F. Muel. & Gordonvale, Australia & 386 & $J M C$ & A) $275083 /$ AJ $298435 /$ \\
\hline Pleistodontes nigriventris (Girault, 1915) & F. watkinsiana F. M. Bailey & Kairi, Queensland, Australia & 412 & JMC & AJ 275084/AJ 298436/AF 284598 \\
\hline Pleistodontes froggatti Mayr, 1906 & F. macrophylla Desf. ex Pers. & Sydney, Australia & 425 & DB & A) $275085 / A J ~ 298437 / A F 284600$ \\
\hline Pleistodontes plebejus Wiebes, 1963 & F. hesperidiiformis King & $\begin{array}{l}\text { Ohu Conservation area, Madang, } \\
\text { Papua New Guinea }\end{array}$ & 429 & $\mathrm{BI}$ & AJ 275088/AJ 298438/AF 284596 \\
\hline Pleistodontes immaturus Wiebes, 1963 & F. sterrocarpa Diels & $\begin{array}{l}\text { Haia, Crater Mountain Wildlife } \\
\text { Management Area, Madang, Papua } \\
\text { New Guinea }\end{array}$ & GW 715 & GW & AJ $298404 /-/-$ \\
\hline $\begin{array}{l}\text { Pleistodontes imperialis Saunders, } 1883 \\
\text { Outgroup }\end{array}$ & F. rubiginosa Desf. ex Vent. & Pallerenda, Townsville, Australia & 3 & CLV & AJ 298405/AJ 298439/AF284584 \\
\hline \multicolumn{6}{|l|}{ Family Agaonidae } \\
\hline Platyscapa soraria Wiebes, 1980 & F. ingens & South Africa & 23 & CM & AJ 298406/AJ 298440/AF 284602 \\
\hline \multicolumn{6}{|l|}{ Family Pteromalidae } \\
\hline \multicolumn{6}{|l|}{ Subfamily Sycoryctinae } \\
\hline Sycoscapter sp. 1. & F. brachypoda nom. provis. & $\begin{array}{l}\text { Ross Highway, East Alice Spring, } \\
\text { Australia }\end{array}$ & $\begin{array}{l}406(\mathrm{PhD} \\
479)\end{array}$ & DD & AJ 298387/AJ 298407/- \\
\hline Sycoscapter sp. 2. & F. obliqua G. Forst & Cooktown, Queensland, Australia & 413 & $J M C$ & AJ 298388/AJ 298408/- \\
\hline Sycoscapter sp. 3 & F. platypoda (Miq) & Kununurra, Western Australia & $\begin{array}{l}\text { 405(PhD } \\
436)\end{array}$ & DD & AJ 298389/AJ 298409/- \\
\hline Sycoscapter sp. 4 & F. obliqua G. Forst & $\begin{array}{l}\text { Atherton Tablelands, Queensland, } \\
\text { Australia }\end{array}$ & $\begin{array}{l}434(\mathrm{PhD} \\
335)\end{array}$ & DD & AJ 298390/AJ 298410/- \\
\hline Sycoscapter sp. 5 & F. cerasicarpa nom. provis & Mount Isa, Australia & $\begin{array}{l}399(\mathrm{PhD} \\
405)\end{array}$ & DD & AJ 298391/AJ 298411/- \\
\hline Sycoscapter sp. 6 & F. lilliputiana nom. provis & Lake Argyle, Western Australia & $\begin{array}{l}\text { 400(PhD } \\
449)\end{array}$ & DD & AJ 298392/AJ 298412/- \\
\hline Sycoscapter sp. 7 & F. subpuberula Corner & $\begin{array}{l}\text { Kununurra, Twin Pools, Western } \\
\text { Australia }\end{array}$ & $\begin{array}{l}403(\mathrm{PhD} \\
442)\end{array}$ & DD & AJ 298393/AJ 298413/- \\
\hline Sycoscapter sp. 8 & F. pleurocarpa F. Muel. & $\begin{array}{l}\text { Upper Cooper Creek, Daintree, } \\
\text { Queensland }\end{array}$ & 402 & CLV & AJ 298394/AJ 298414/- \\
\hline Sycoscapter sp. 9 & F. triradiata Corner & $\begin{array}{l}\text { Mount Windsor, Atherton Tablelands, } \\
\text { Australia }\end{array}$ & $\begin{array}{l}\text { 401(PhD } \\
354)\end{array}$ & DD & AJ 298395/AJ 298415/ \\
\hline Sycoscapter sp. 10 & F. crassipes F. M. Bailey & $\begin{array}{l}\text { Upper Cooper Creek, Daintree, } \\
\text { Queensland }\end{array}$ & 407 & CLV & AJ 298396/AJ 298416/- \\
\hline Sycoscapter sp. 11 & F. glandifera Summerh. & $\begin{array}{l}\text { Keravat. East New Britain, Papua New } \\
\text { Guinea }\end{array}$ & 411(CLV01) & CLV & AJ 298397/AJ 298417 \\
\hline Sycoscapter sp. 12 & F. xylosycia Diels & $\begin{array}{l}\text { Raunsepna, East New Britain, Papua } \\
\text { New Guinea }\end{array}$ & 410(CLV11) & CLV & AJ 298398/AJ 298418/- \\
\hline Sycoscapter sp. 13 & F. watkinsiana F. M. Bailey & Kairi, Queensland, Australia & 409 & $J M C$ & AJ 298399/-/- \\
\hline Sycoscapter australis & F. macrophylla Desf. ex Pers. & Sydney, Australia & 418 & DB & AJ 298400/AJ 298419/- \\
\hline Sycoscapter sp. 14 & F. hesperidiiformis King & $\begin{array}{l}\text { Ohu Conservation area, Madang, } \\
\text { Papua New Guinea }\end{array}$ & 430 & $\mathrm{BI}$ & AJ 298401/AJ 298420/- \\
\hline Sycoscapter sp. 15 & F. rubiginosa Desf. ex Vent. & Pallerenda, Townsville, Australia & 404 & CLV & AJ 298402/AJ 298421/- \\
\hline \multicolumn{6}{|l|}{ Outgroup } \\
\hline \multicolumn{6}{|l|}{ Family Pteromalidae } \\
\hline \multicolumn{6}{|l|}{ Subfamily Sycoryctinae } \\
\hline Philotrypesis sp. & F. rubiginosa & Pallerenda, Townsville, Australia & 416 & CLV & AJ 298403/AJ 298422/- \\
\hline
\end{tabular}

${ }^{a}$ Figures between parentheses correspond to the plant voucher specimen deposited in Dale Dixon's herbarium at J ames Cook University, Townsville, Australia.

${ }^{\mathrm{b}}$ coll, collectors; CLV, Carlos Lopez-Vaamonde; CM, Carlos Machado; J MC, J ames Cook; DD, Dale Dixon; GW, George Weiblen; I GC, I rene G. Champion; J L, J ohn Lattke; DB, Daniel Bean; BI, Brus Isua. 
Total genomic DNA was extracted from single individuals in $50 \mu \mathrm{l}$ of an extraction buffer containing $2 \%$ Chelex 100 Resin (Bio-Rad) (Singer-Sam et al., 1989), as described by West et al. (1998). Double-stranded PCR amplifications were performed with Ready-to-go PCR beads (Amersham, Pharmacia Biotech) with $2 \mu \mathrm{l}$ of DNA extract and $10 \mathrm{pmol}$ of each primer in a $25-\mu \mathrm{l}$ reaction volume. The primers used in both amplification and sequencing were CB1 ( $5^{\prime}$ TAT GTA CTA CCA TGA GGA CAA ATA TC) and CB2 (5' ATT ACAC CTC CTA ATT TAA TTA GGA AT) for the cyt b gene (J ermiin and Crozier, 1994), ITSF (5' ATT CCC GGA CCA CGC CTG GCT GA) and ITSR (5' CGC CTG ATC TGA GGT CGT C) for the ITS2 gene (Campbell et al., 1993), and DIF (5' ACC CGC TGA ATT TAA GCA TAT) (Harry et al., 1996) and D3R (5' TAG TTC ACC ATC TTT CGG GTC) for the $28 \mathrm{~S}$ gene. PCR conditions were 40 cycles at $94^{\circ} \mathrm{C}$ for $1 \mathrm{~min}$, an annealing step at $47^{\circ} \mathrm{C}$ for $1 \mathrm{~min}$, and an extension step at $72^{\circ} \mathrm{C}$ for $90 \mathrm{~s}$ for the cyt b gene; $3 \mathrm{~min}$ at $93^{\circ} \mathrm{C}$ followed by 30 cycles of $98^{\circ} \mathrm{C}$ (15 s), $50^{\circ} \mathrm{C}(30 \mathrm{~s})$, and $72^{\circ} \mathrm{C}(40 \mathrm{~s})$ and a final extension of $72^{\circ} \mathrm{C}$ for $3 \mathrm{~min}$ for the ITS2 gene; and $3 \mathrm{~min}$ at $93^{\circ} \mathrm{C}$ followed by $35 \mathrm{cycles}$ of $98^{\circ} \mathrm{C}(15 \mathrm{~s}), 57^{\circ} \mathrm{C}(30 \mathrm{~s})$, and $72^{\circ} \mathrm{C}(40 \mathrm{~s})$ and a final extension of $72^{\circ} \mathrm{C}$ for $3 \mathrm{~min}$ for the $28 \mathrm{~S}$ rDNA gene. All PCR products were purified with the GFX PCR DNA and gel band purification kit (Amersham, Pharmacia Biotech) and then sequenced directly with an ABI PRISM BigDye terminator cycle sequencing ready reaction kit (Perkin-Elmer Biosystems) on an ABI 3700 automated sequencer. All products were sequenced in both directions. Chromatograms were edited and sequences (not including primers) compiled with Sequencher 3.0 (Gene Codes Corp., Ann Arbor, MI) and submitted to GenBank (Table 1).

Intragenomic variation in ITS2 is known to exist in insects (Wesson et al., 1992) and divergent paralogous sequences can seriously confound species phylogenies (Buckler et al., 1997). We therefore investigated ITS2 sequence variation within three species (Pleistodontes rigisamos, P. imperial is, and P. froggatti) by repeated PCR amplification and direct sequencing both of the same individual and of multiple individuals of each species.

\section{Sequence Alignment and Phylogenetic Analyses}

Cyt b sequences were all 381 bp (Pleistodontes) or 417 bp (Sycoscapter) long. They could be aligned by eye unambiguously, and all had full open reading frames. On the other hand, both 28S and ITS2 showed substantial variation in length across species: 28S (1019-1038 bp in Pleistodontes, 742-751 bp in Sycoscapter) and ITS2 (291- 413 bp in Pleistodontes). Distance-based sequence alignments were performed with Clustal W (Higgins and Sharp, 1988) with default settings (Open Gap Penalty = 10.0; Extend Gap Penalty = 5.0; Delay Divergent $=40 \%$; Transitions: weighted). Alignments are available from TreeBASE (http://www.herbaria. harvard.edu/treebase/console.html).

All phylogenetic analyses were conducted with PAUP* 4.0b2a (Swofford, 1999). Each gene was first analyzed independently and the signals from different genes were then compared by ILD tests. All parsimonyuninformative characters were removed before the test was used (Cunningham, 1997), which was run with 1000 replicates and 50 random stepwise additions of taxa (the "partition homogeneity test" option in PAUP*). Subsequently, congruent data sets were combined for further analysis (Bull et al., 1993; Huelsenbeck et al., 1996a).

Both maximum-parsimony (MP) (Farris, 1970) and maximum-likelihood (ML) (Felsenstein, 1981) analyses were performed. Wherever possible, MP trees were reconstructed with the branch-and-bound search method (Hendy and Penny, 1982). When these proved too computer intensive, we used heuristic searches, involving TBR branch swapping with 1000 random stepwise additions of taxa. Gaps were treated as a fifth state and all character transitions were given equal weighting. MacClade v. 4 (Maddison and Maddison, 2000) was used to calculate the average nucleotide frequencies and the number of Ts and TV at each Cyt $b$ codon position.

F or the ML analyses, the best model of DNA substitution was selected by Model test3.0 (Posada and Crandall, 1998), which uses two criteria, the ML ratio test and the Akaike information criterion (AIC; Akaike, 1974). When the criteria favored different models, we compared the resulting topologies using the Shimodaira-Hasegawa test (SH) (Shimodaira and Hasegawa, 1999; Goldman et al., 2000), implemented in SHTest version 1.0 using the RELL model and 1000 bootstrap replicates (Rambaut, 2000). A ML heuristic search (options: ASIS and TBR branch-swapping) was then run under the likelihood settings (empirical base frequencies, Ts/Tv ratio, proportion of invariable sites, and gamma shape parameter) estimated with Modeltest 3.0.

Support for individual nodes was evaluated by nonparametric bootstrapping (BV) (Felsenstein, 1985) with either 300 (ML) or 1000 replicates. We also measured the skew (g1) in the distribution of cladogram lengths (DCL) (Huelsenbeck, 1991) for each gene, based on 10,000 randomly generated trees, as an indicator of phylogenetic signal. Finally, the leaf stability (Thorley and Wilkinson, 1999) of each taxon was estimated with RadCon version 1.0.0 (Thorley and Page, 1999).

Species from several fig wasp genera were assessed for use as outgroups. These were Ceratasolen (C) arabi cus (Mayr, 1906), Pegoscapus gemellus Wiebes, 1995, Tetrapus costaricanus (Grandi, 1925), Wiebesia punctatae Wiebes, 1992, and Platyscapa soraria Wiebes, 1980 for pollinating wasps and Robertsia sp., Dobun- 
abaa sp., Tenka sp., Watshamiella sp., and Philotrype sis sp. for nonpollinating wasps. An initial MP analysis was performed with $\mathrm{T}$. costaricanus and Robertsia sp. as outgroups to identify which of the other fig wasp genera was an appropriate outgroup for Pleistodontes and Sycoscapter, respectively.

\section{Cospeciation Tests}

To test for parallel cladogenesis we followed the procedure illustrated by the flow chart in Fig. 1 (see also Huelsenbeck et al., 2001). First, we tested the null hypothesis $(\mathrm{H} 1)$ that Pleistodontes and Sycoscapter trees are not more congruent than two independent phylogenies generated under a random branching model, using a maximum cospeciation analysis implemented in the Treemap 1.0 package (Page, 1995). The Sycoscapter phylogeny was mapped onto the Pleistodontes phylogeny to maximize the number of cospeciation events in the absence of host switching (Page, 1994; Page and Charleston, 1998). The probability of obtaining the observed number of cospeciation events was then calculated by randomization of both the Sycoscapter and the Pleistodontes trees 1000 times to generate a null frequency distribution (and hence test statistic). P values were corrected for problems with the randomization routine (see http://taxonomy. zoology.gla.ac.uk/rod/treemap.html for details) with the proportional-to-distinguishable model instead of the Yule (Markovian) model to generate random trees. The percentage of cospeciating nodes is simply the number of cospeciating nodes inferred by Treemap, divided by the total number of nodes in the parasite phylogeny, and then multiplied by 100. Only fully re- solved host and parasite trees were compared (a limitation of Treemap).

$\mathrm{SH}$ tests were used to compare alternative MP and ML topologies derived from the Clustal alignment. If no significant difference was found, the ML topology alone was used; otherwise all topologies were investigated.

When $\mathrm{H} 1$ was rejected, we used the parsimony-based ILD (J ohnson et al., 2001; J ohnson and Clayton, 2001) and the likelihood-based SH tests to test whether pollinator and parasite data sets were consistent with complete congruence $(\mathrm{H} 2)$.

\section{RESULTS}

\section{Characterization of Nucleoti de Patterns}

Sycoscapter species show slightly higher levels of uncorrected nucleotide divergence for both 28S D2-D3 (1- 6\% compared to $0.01-4.6 \%$ for Pleistodontes) and Cyt b (4-23\% compared to 3-19\% for Pleistodontes). These differences in the level of divergence were statistically significant (28S: $t=-8.063, \mathrm{df}=208, \mathrm{P}>$ 0.0001 ; Cyt b: $\mathrm{t}=-2.540, \mathrm{df}=208, \mathrm{P}>0.05)$ by $\mathrm{t}$ tests (see Discussion).

PCR amplification of ITS2 yielded single bands, and uncorrected $\mathrm{p}$ distances between Pleistodontes species varied from 3 to $62 \%$. The generally high genetic distances were primarily due to a number of microsatellite loci near the 3' end of ITS2. The presence of microsatellites in ITS2 has been documented in other Chalcidoidea (Campbell et al., 1993) and, to control for distorting effects (Harris and Crandall, 2000), phylo-

TABLE 2

Nucleotide and Amino Acid Patterns

\begin{tabular}{|c|c|c|c|c|c|c|c|c|c|}
\hline & A & C & G & $\mathrm{T}$ & $\mathrm{P}$ & $\mathrm{Ts} / \mathrm{Tv}^{\mathrm{a}}$ & $n$ & $\mathrm{nv}$ & ic \\
\hline \multicolumn{10}{|l|}{ Pleistodontes } \\
\hline $28 \mathrm{~S} D 1+\mathrm{D} 3$ & 26.62 & 23.73 & 28.92 & 20.73 & - & & 1038 & 249 & 95 \\
\hline Cyt b total sequence & 33.3 & 13.5 & 9.8 & 43.5 & & $0.81-0.82$ & 381 & 155 & 105 \\
\hline Cyt b (1st) & 32.24 & 15.47 & 17.14 & 35.15 & - & 2.03 & 127 & 37 & 25 \\
\hline Cyt b (2nd) & 25.20 & 18.99 & 11.21 & 44.60 & - & $0.60-0.69$ & 127 & 21 & 7 \\
\hline Cyt b (3rd) & 42.47 & 5.97 & 0.93 & 50.62 & * & $0.62-0.64$ & 127 & 97 & 73 \\
\hline Amino acids & & & & & & & 127 & 38 & 22 \\
\hline ITS2 & 19.94 & 24.70 & 30.56 & 24.79 & - & & 413 & 298 & 210 \\
\hline \multicolumn{10}{|l|}{ Sycoscapter } \\
\hline $28 \mathrm{~S} D 2+\mathrm{D} 3$ & 23.01 & 25.22 & 30.18 & 21.58 & - & & 751 & 133 & 70 \\
\hline Cyt b total sequence & 31.6 & 14.3 & 9.2 & 44.9 & & $0.87-0.88$ & 417 & 203 & 139 \\
\hline Cyt b (1st) & 33.40 & 14.88 & 16.39 & 35.33 & - & $1.26-1.28$ & 139 & 65 & 36 \\
\hline Cyt b (2nd) & 23.36 & 20.82 & 9.92 & 45.89 & - & $2.7-2.88$ & 139 & 21 & 10 \\
\hline Cyt b (3rd) & 39.46 & 5.04 & 1.33 & 54.17 & * & $0.65-0.67$ & 139 & 117 & 93 \\
\hline Amino acids & & & & & & & 139 & 45 & 31 \\
\hline
\end{tabular}

Note $A, C, G, T$, average nucleotide frequencies; $P, \chi^{2}$ test of homogeneity of base frequencies across taxa: *P $\leq 0.05 ;-$, not significant $(\mathrm{P}>0.05)$; Ts/Tv, transition transverstion ratio; $\mathrm{n}$, total number of positions; nv, number of variable positions; ic, number of parsimony informative characters.

${ }^{a}$ The numbers of Ts and Tv were estimated as changes reconstructed on the MP tree and were not merely calculated from pairwise distances (Madison and Madison, 2000). 
TABLE 3

Summary of Tree Statistics for Each Data Set under Unweighted MP Analysis and ML

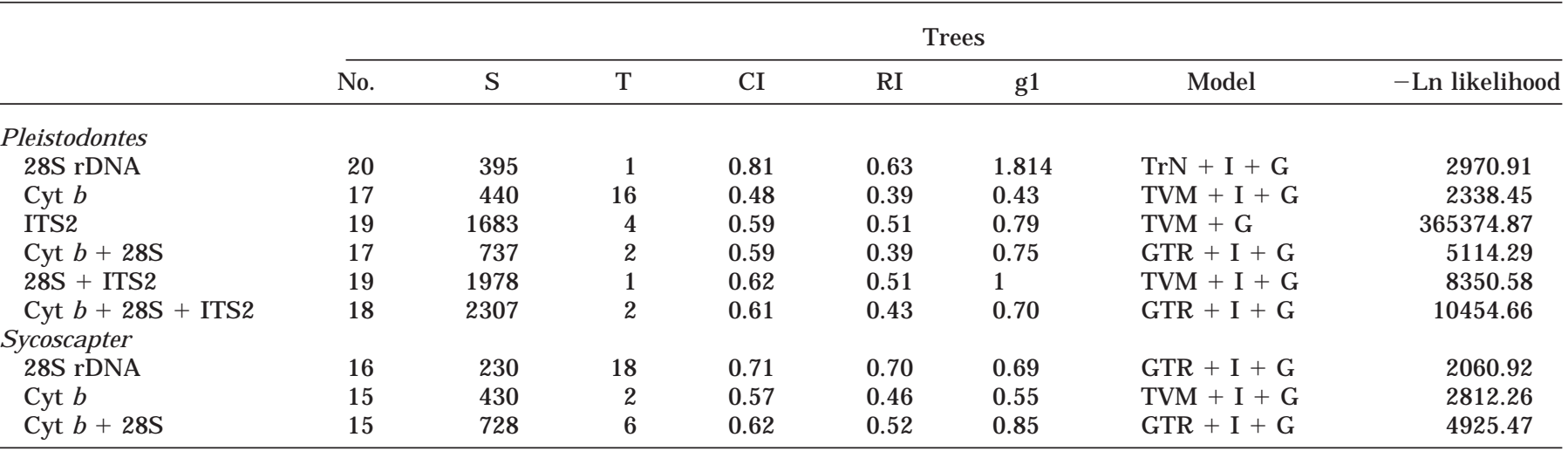

Note. No., number of ingroup taxa; S, length of most parsimonious cladogram; $\mathrm{T}$, number of most parsimonious trees; $\mathrm{Cl}$, consistency index; $\mathrm{RI}$, retention index; $\mathrm{g}_{1}$, frequency distribution of cladograms length skewness; - Ln likelihood, score of best tree found; TrN, Tamura-Nei model (Tamura and Nei, 1993); I, proportion of invariable sites; G, shape parameter of the gamma distribution; TVM, submodel of the general time reversible model (Yang, 1994); GTR, general time reversible model (Rodriguez et al., 1990).

genetic analyses were carried out with and without these regions. Comparisons of multiple sequences from the same individual, or from two different specimens of the same species (tested for $P$. rigi samos, P. imperial is, and $P$. froggatti), showed $<5 \%$ sequence divergence, suggesting that paralogues were not highly divergent or not amplified. These sequences varied in the number of repeats within the repetitive motif regions near the $3^{\prime}$ end of the fragment.

Average nucleotide frequencies are shown in Table 2. There is strong A-T bias in Cyt b,as noted in other fig wasps (Kerdelhue et al., 1999) and Hymenoptera in general (J ermiin and Crozier, 1994). This is reflected in the overall excess of Tv over Ts (Ts/Tv $=0.8)$ and is especially marked at 3rd codon positions (Ts/Tv $=0.6)$. In contrast, a higher Ts/Tv ratio occurs at the 1st codon position in Pleistodontes (2.03) and at the 2nd codon position in Sycoscapter (2.7-2.9) due to several $T$ to $C$ transitions.

In both Pleistodontes and Sycoscapter, the majority of phylogenetic information occurred at the 3rd, followed by the 1st and 2nd codon positions. Comparison of $p$ distances with TVM corrected distances revealed minimal saturation at 1st and 2nd codon positions but high saturation at 3rd codon positions. Plots of Ts/Tv against uncorrected $\mathrm{p}$ distances for each codon confirmed this pattern and that Ts/Tv ratios are also higher between closely related species. There was also significant heterogeneity in nucleotide composition at 3rd codon positions of Cyt $b$.

Phylogenetic Analyses

Modeltest 3.0 identified the general time reversible model (GTR; Rodriguez et al. 1990; Yang et al., 1994) as appropriate for most (but not all) data sets (Table 3). Pleistodontes and Sycoscapter trees from (condition- ally) combined analyses under different optimality criteria are shown in Figs. 2-5. Summary statistics for $M P$ and $M L$ analyses of each data set are given in Table 3.

Pleistodontes phylogeny. MP analyses of individual genes yielded poorly resolved trees with few clades supported by BV $>50 \%$. The only clade that was consistently highly supported (>90\%) was a group of four western Australian species ( $P$. cuneatus $+P$. proximus + P astrabocheilus + P. spec. nov. 2). Phylogenetic signal (g1) was lowest for Cyt b,consistent with the poor signal of this region in the fig-pollinating genus Ceratosolen (Kerdelhue et al., 1999). Removal of the ITS2 microsatellite region did not yield a significantly different topology but reduced bootstrap support for most nodes. Consequently we retained this region in combined analyses.

The Cyt b data set showed significant conflict with ITS2 but there was no conflict between $28 \mathrm{~S}$ and ITS2 (Table 4). Consequently, we combined 28S + ITS2 as our preferred data set and also $28 \mathrm{~S}+$ Cyt b. Not surprisingly, the $28 \mathrm{~S}+$ Cyt b Pleistodontes phylogeny was poorly resolved with few well-supported nodes and low leaf stability values for most species (Fig. 2). The clade of $P$. froggatti and $P$. regalis (both species with a mandibular appendage that bears ventral rows of small teeth instead of ventral lamellae) was recovered. Another interesting clade is $P$. greenwoodi and $P$. xanthocephalus (both pollinators of $F$. obliqua) which appeared in the 28S MP tree and was recovered in Cyt b only when Ts were removed from 3rd codon positions. There was no significant difference between MP and ML topologies (Table 5).

On the other hand, the 28S + ITS2 topology was completely resolved and many nodes were well sup- 
$28 S$ rRNA + Cyt b

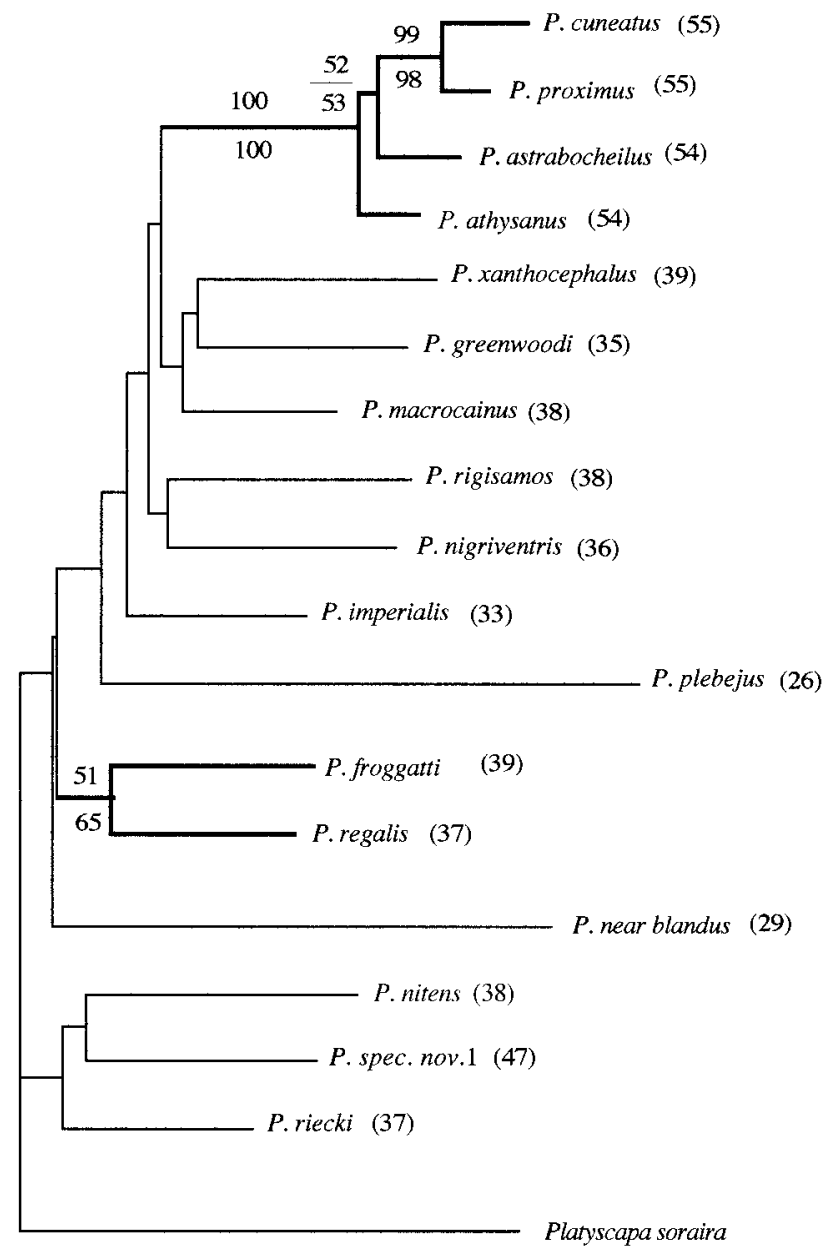

0.01 substitutions/site

FIG. 2. $M L$ tree based on combined $28 \mathrm{~S}$ and Cyt b sequence data for 17 Pleistodontes species (13 Australian and 4 New Guinean). P. schizodontes, P. immaturus, and P. blandus have not been sequenced for Cyt b and are not included. - In likelihood $=$ 5130.27. Model parameters: empirical base frequencies with rate heterogeneity; gamma shape parameter $=0.5827$; proportion of invariable sites $=$ 0.6007; six rate categories; GTR + I + G model with transformation parameters $[\mathrm{A}-\mathrm{C}]=1.2896,[\mathrm{~A}-\mathrm{G}]=5.3805,[\mathrm{~A}-\mathrm{T}]=12.4806,[\mathrm{C}-\mathrm{G}]$ $=1.8212$, $[\mathrm{C}-\mathrm{T}]=17.2534,[\mathrm{G}-\mathrm{T}]=1.00$. Branch lengths are proportional to lengths estimated under the $\mathrm{ML}$ model. Boldface lines show clades present in both MP and ML analyses. Percentage bootstrap support (1000 replications) is indicated above branches for ML and below branches for MP. Leaf stability values are given between parentheses next to the terminal taxa.

ported. The MP (Fig. 3) and ML topologies (Fig. 4) were not significantly different (Table 5). We nevertheless retained both topologies for subsequent Treemap analyses, to examine the sensitivity of our cospeciation analysis to different optimality criteria. The western Australian clade is recovered in both MP and ML trees, as is the P. greenwoodi-P. xanthocephalus clade. The species $P$. regalis is basal due largely to the extreme divergence of its ITS2 sequence. There was no conflict between well-supported clades (BV >50\%) in the $28 \mathrm{~S}+$ Cyt b and 28S + ITS2 topologies.

Sycoscapter phylogeny. There was no conflict between 28S D2-D3 and Cyt b data partitions (Table 4), and total phylogenetic structure (g1) increased when the genes were combined (Table 3). The Sycoscapter phylogeny resulting from the combined analysis was completely resolved and well supported (Fig. 5), and the MP and ML topologies were not significantly different (Table 5). We therefore present only the combined ML tree (Fig. 5). Sycoscapter ex F. macrophylla was the only species to lack good leaf stability and its

\section{MP 28S rRNA + ITS2}

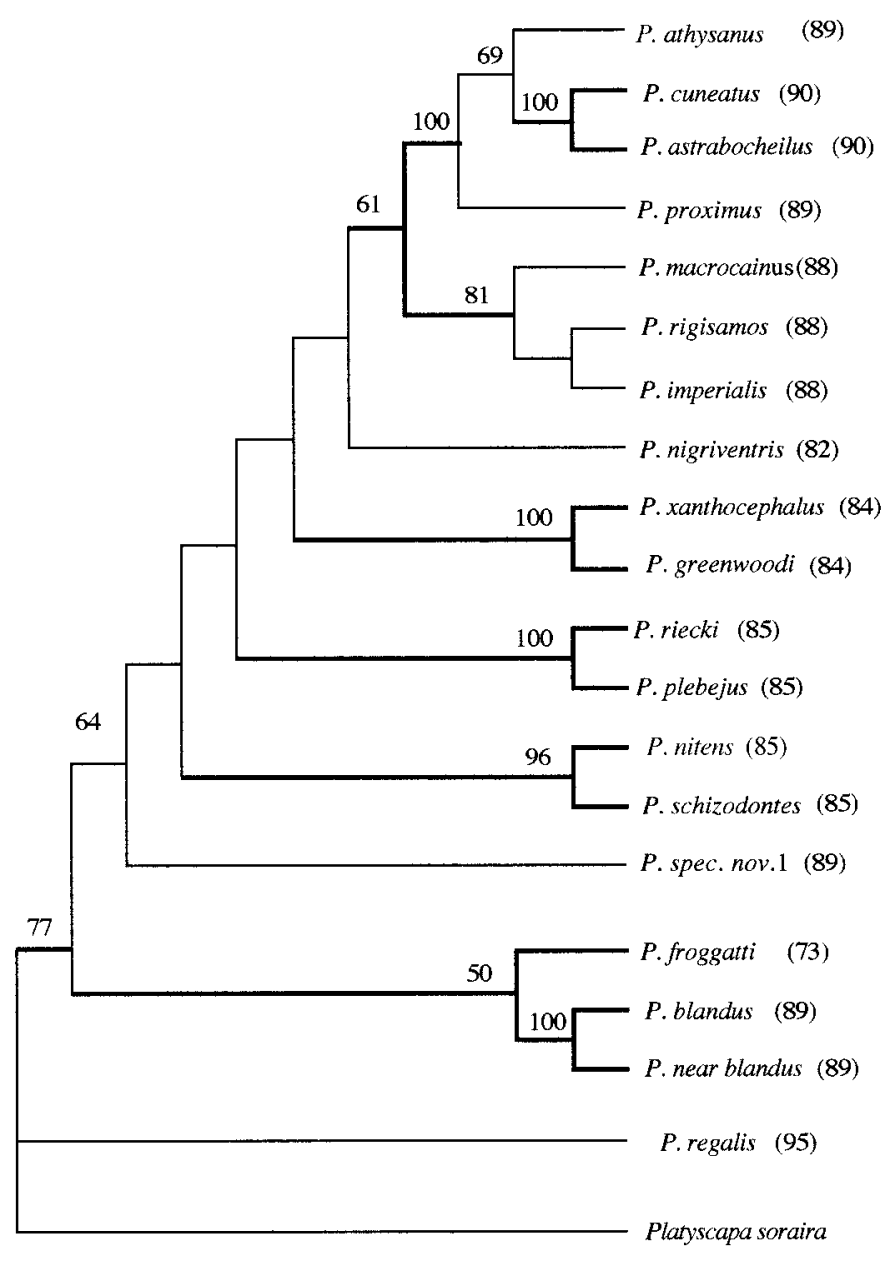

FIG. 3. Most-parsimonious tree of 19 Pleistodontes species (14 Australian and 5 New Guinean) for which both $28 \mathrm{~S}$ and ITS2 sequence data were available. Boldface lines show clades present in both MP and ML analyses. Leaf stability values are given between parentheses next to the terminal taxa. Unlabeled branches had bootstrap support lower than $50 \%$. 


\section{28S rRNA + ITS2}

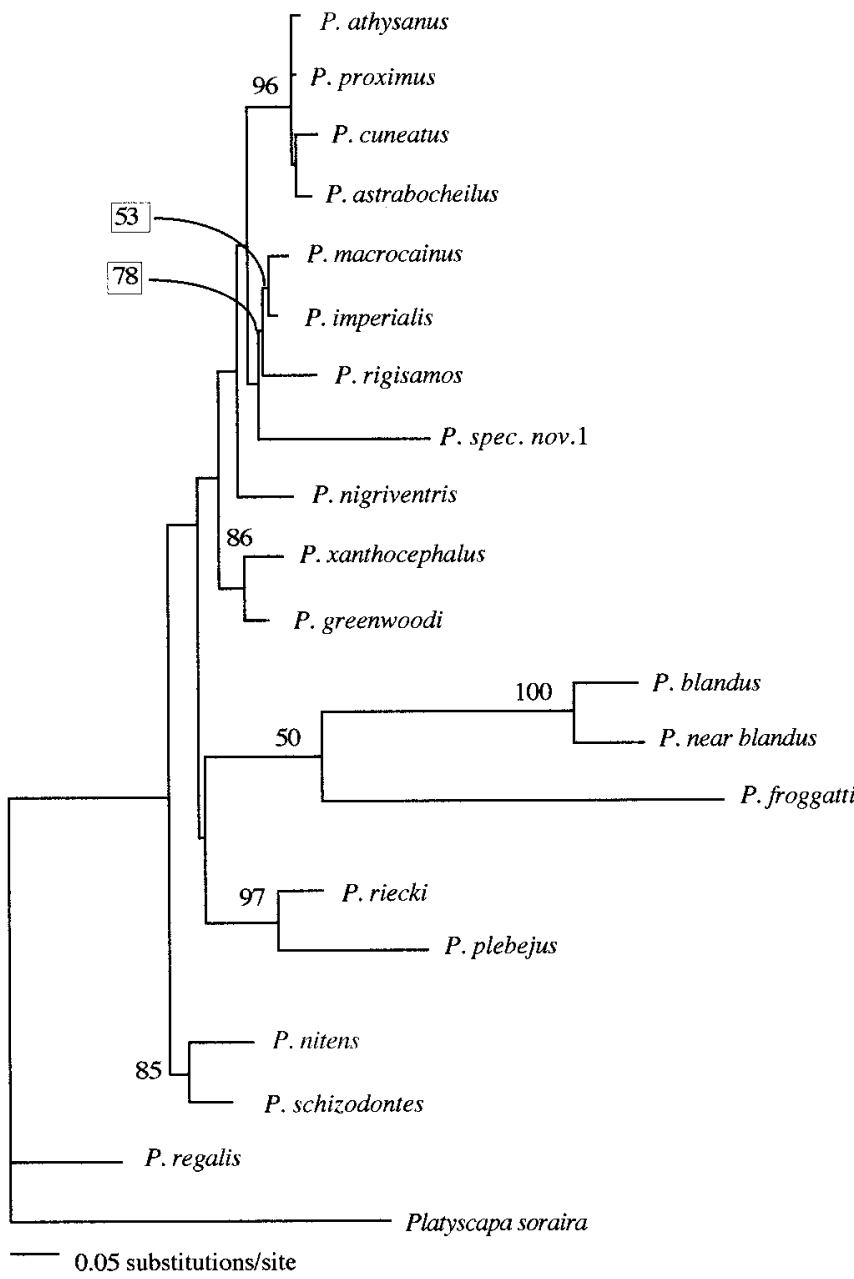

FIG. 4. ML tree based on combined $28 \mathrm{~S}$ and ITS2 for the same 19 Pleistodontes species as those in Fig. 3. - In likelihood $=8350.58$. Model parameters: empirical base frequencies with rate heterogene ity; gamma shape parameter $=0.365$; proportion of invariable sites $=0.3648$; six rate categories; TVM + I + G model with transformation parameters $[\mathrm{A}-\mathrm{C}]=0.8134,[\mathrm{~A}-\mathrm{G}]=2.7801,[\mathrm{~A}-\mathrm{T}]=1.6023$, $[\mathrm{C}-\mathrm{G}]=0.6608,[\mathrm{C}-\mathrm{T}]=2.7801,[\mathrm{G}-\mathrm{T}]=1.00$. Branch lengths are proportional to lengths estimated under the ML model. Bootstrap values $>50 \%$ are shown.

position depended on the outgroup. When Phil otrypesis (the sister genus of Sycoscapter) was used as the outgroup, S. ex F. macrophylla appears as sister to the rest of Malvanthera-feeding Sycoscapter species. However, when African Sycoscapter species were used as outgroups, it appeared as the sister group to the western Australian species.

\section{Are Pleistodontes and Sycoscapter Topologies Independent?}

Treemap was used to compare the Sycoscapter ML phylogeny with three Pleistodontes trees: (a) the ML tree derived from $28 \mathrm{~S}+$ Cyt b (ML1), (b) the $28 \mathrm{~S}+$ ITS $M L$ tree (ML2), and (c) the $28 S$ + ITS MP tree (MP). The level of cospeciation estimated ranged from 50 to $64 \%$ and was significant for ML 2 and MP trees but not for the poor-quality $28 \mathrm{~S}+$ Cyt b tree (Table 7).

The highest estimate of cospeciation was obtained with the MP Pleistodontes topology (Fig. 3); an exact search in Treemap identified 17 optimal reconstructions, each with nine cospeciating nodes, but differing in duplication (1-3), host switching (2-5), and sorting events (11-18). Comparison with randomized trees (Fig. 7) allows us to reject $\mathrm{H} 1$ with $\mathrm{P}=0.001$ and with $P=0.008$ with a conservative correction suggested by Taylor and Purvis (2001).

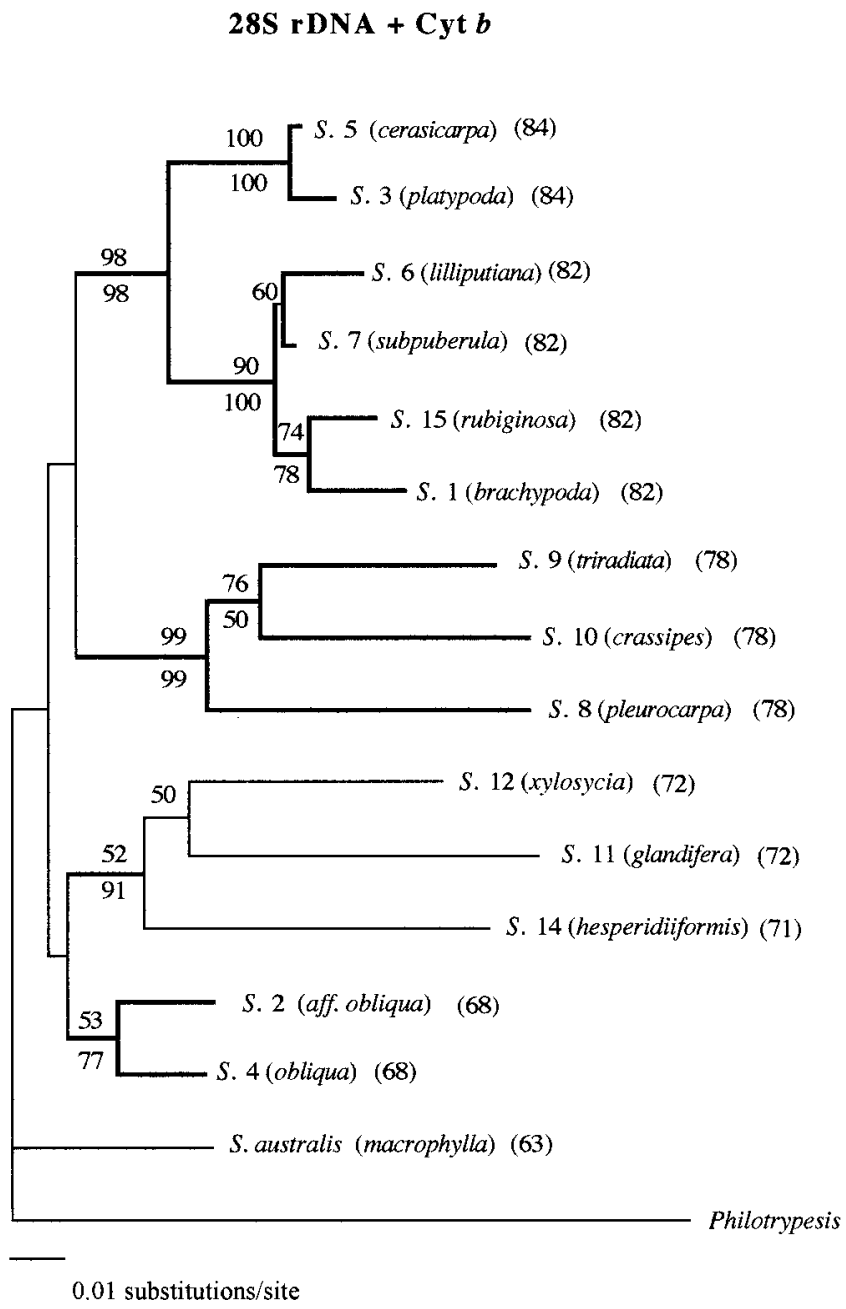

FIG. 5. ML tree based on the combination of $28 \mathrm{~S}+\mathrm{Cyt} b \mathrm{ML}$ for 15 Sycoscapter species (12 Australian and 3 New Guinean). -In likelihood $=4925.46682$. Model parameters: empirical base frequencies with rate heterogeneity; gamma shape parameter $=0.7437$; proportion of invariable sites $=0.4514$; GTR + I + G model with transformation parameters $[\mathrm{A}-\mathrm{C}]=2.5474,[\mathrm{~A}-\mathrm{G}]=8.7791,[\mathrm{~A}-\mathrm{T}]=$ 12.6510, $[\mathrm{C}-\mathrm{G}]=2.1232,[\mathrm{C}-\mathrm{T}]=18.4266,[\mathrm{G}-\mathrm{T}]=1.00$. Conventions as in Fig. 4. 


\section{TABLE 4}

\section{Results of the ILD Congruence Test between} Different Data Sets

Data sets compared

285 Pleistodontes vs cyt b Pleistodontes 28S Pleistodontes vs ITS2 Pleistodontes cyt b Pleistodontes vs ITS2 Pleistodontes 285 Sycoscapter vs cyt b Sycoscapter $28 S$ Pleistodontes vs 285 Sycoscapter cyt b Pleistodontes vs cyt b Sycoscapter 28S Pleistodontes vs cyt b Sycoscapter cyt b Pleistodontes vs 285 b Sycoscapter ITS2 Pleistodontes vs 28S Sycoscapter ITS2 Pleistodontes vs cyt b Sycoscapter

Note. The incongruence threshold is $\mathrm{P}<0.05$ and the combinable data sets are highlighted in boldface.

\section{Do Pleistodontes and Sycoscapter Datasets Support the Same Topology?}

With $\mathrm{H} 1$ rejected, we can consider $\mathrm{H} 2$, that the underlying Pleistodontes and Sycoscapter phylogenies are identical. If H2 is accepted, the level of incongruence found in the Treemap analysis could be attributed to phylogenetic uncertainty (weakly supported conflicting nodes). On the other hand, rejection of $\mathrm{H} 2$ would suggest that incongruence is based on real differences in speciation patterns. ILD tests (Table 4) and SH tests (Table 6) both indicated highly significant incongruence between all pairwise combinations of Pleistodontes and Sycoscapter data sets. The rejection of $\mathrm{H} 2$ precludes testing of $\mathrm{H} 3$ on comparative rates of molecular evolution and timing of cospeciation events (see Fig. 1), as this requires perfect concordance of clade or subclade topologies (Hafner et al. 1994; Huelsenbeck et al., 1997).

\section{DISCUSSION}

\section{Partial Cocladogenesis of Pleistodontes and}

\section{Sycoscapter}

This study demonstrates partial congruence of the molecular phylogenies of Pleistodontes pollinating wasps and their ecologically associated Sycoscapter nonpollinating wasps. Congruence is significantly greater than that expected by chance but significantly less than that expected under perfect cospeciation. Overall, the level of sequence variation was appropriate to resolve the interacting phylogenies but the degree of resolution and support was far better for Sycoscapter than for Pleistodontes. The Pleistodontes $28 \mathrm{~S}+$ ITS2 tree, and especially the single best Sycoscapter tree, represent robust estimates of phylogeny upon which to base tests of cospeciation.

There are no major clades in the two phylogenies that correspond exactly. I $\mathrm{n}$ fact, perfect correspondence is seen only between two terminal pairs of pollinator and parasite sister species. The first of these is $P$. xanthocephalus/S.2 + P. greenwoodi/S.4 and the second is P. schizodontes/S.9 + P. nitens/S.10. Whereas these might represent two recent cospeciation events, overall the partial congruence level observed generates too many optimal reconstructions to infer, with confidence, particular cospeciation, host switching, duplication, or sorting events (see also Clark et al., 2000). Nevertheless, the overall percentage (50-64\%) of cospeciating nodes falls within the range of values observed for other putatively coevolved interactions (TayIor and Purvis, 2001). For example, analysis of the textbook example of pocket gophers and lice identified $62.5 \%$ cospeciating nodes (Hafner et al., 1994), and a broader survey of mammals and chewing lice yielded estimates of $20-75 \%$ for different clades (Taylor and Purvis, 2001).

Simple demonstration that there is a greater than random match between two sets of taxa does not per se demonstrate cospeciation, since many different ecological and biogeographical scenarios can result in partial congruence (Clark et al., 2000). For example, resource tracking (Kethley and J ohnston, 1975) and sequential evolution (J ermy, 1976) models both predict partial phylogenetic congruence of interacting clades, without implying synchronous speciation. In addition, concordant speciation may be caused by extrinsic factors such as vicariance, although this is unlikely for the fig wasps in question.

\section{TABLE 5}

Shimodaira-Hasegawa Test Results: Statistical Difference between ML and MP Topologies Obtained from Same Dataset

\begin{tabular}{cccc}
\hline Trees & LnL & Delta & $\begin{array}{c}\text { P } \\
\text { (delta) }\end{array}$ \\
\hline $\begin{array}{c}\text { Pleistodontes } \\
\text { 28S + Cyt b }\end{array}$ & & & \\
MP & -5233.742038 & 3.276152 & 0.430 \\
ML1 & -5230.465886 & 0.000000 & 1.000 \\
ML2 & -5230.465886 & 0.000000 & 1.000 \\
28S + ITS2 & & & \\
MP & -8427.769935 & 5.445047 & 0.293 \\
ML & -8422.324888 & 0.000000 & 1.000 \\
Sycoscapter & & & \\
28S + Cyt b & & & \\
MP1 & -4986.192497 & 8.742769 & 0.272 \\
MP2 & -4984.841368 & 7.391640 & 0.338 \\
MP3 & -4984.416198 & 6.966470 & 0.392 \\
MP4 & -4987.106189 & 9.656460 & 0.247 \\
MP5 & -4985.754901 & 8.305173 & 0.301 \\
MP6 & -4985.355363 & 7.905635 & 0.335 \\
ML & -4977.449728 & 0.000000 & 1.000 \\
\hline
\end{tabular}

Note. LnL, - Ln likelihood, score of best tree found; Delta, difference between the likelihoods of trees; $\mathrm{P}$ (delta), the probability of getting an equal or larger delta if the null is true. This is obtained from a distribution of deltas obtained by bootstrapping. 
TABLE 6

Results of Shimodaira-Hasegawa Test

\begin{tabular}{|c|c|c|c|c|}
\hline Dataset & Tree & $\operatorname{Ln}(L)$ & Delta & $\mathrm{P}$ (delta) \\
\hline \multirow[t]{3}{*}{ Pleistodontes $28 \mathrm{~S}+$ Cyt b } & Pleistodontes $28 \mathrm{~S}+$ Cyt b & -4613.921450 & 0.000000 & 1.000000 \\
\hline & Pleistodontes 28S + ITS2 & -4667.350733 & 53.429283 & 0.014000 \\
\hline & Sycoscapter $28 \mathrm{~S}+$ Cyt b & -4772.833530 & 158.91208 & $<0.000001$ \\
\hline \multirow{3}{*}{ Pleistodontes $28 \mathrm{~S}$ + ITS2 } & Pleistodontes $28 \mathrm{~S}+$ ITS2 & -7159.508394 & 0.000000 & 1.000000 \\
\hline & Pleistodontes $28 \mathrm{~S}+$ Cyt b & -7265.083200 & 105.57481 & $<0.000001$ \\
\hline & Sycoscapter $28 \mathrm{~S}+$ Cyt b & -7354.990855 & 195.48246 & $<0.000001$ \\
\hline \multirow[t]{3}{*}{ Sycoscapter $28 \mathrm{~S}+$ Cyt b } & Sycoscapter $28 \mathrm{~S}+$ Cyt b & -9349.680092 & 0.000000 & 1.000000 \\
\hline & Pleistodontes $28 \mathrm{~S}+$ Cyt b & -9174.360082 & 175.32001 & $<0.000001$ \\
\hline & Pleistodontes $28 \mathrm{~S}+$ ITS2 & -9194.231292 & 155.44880 & $<0.000001$ \\
\hline
\end{tabular}

Note Ln likelihoods of Pleistodontes and Sycoscapter trees under alternative datasets. Each data set was tested against each ML tree generated from successive data sets, where only the taxa in common to each pair of data sets being compared were used. P values represent the probability that the score of the maximum-likelihood tree for a given dataset is significantly higher than that of alternative topologies. $\mathrm{LnL},-\mathrm{Ln}$ likelihood, score of best tree found; Delta, difference between the likelihoods of trees; $\mathrm{P}$ (delta), the probability of getting an equal or larger delta if the null is true. This is obtained from a distribution of deltas obtained by bootstrapping.

Our study generated estimates of cospeciation levels (50-64\%) very similar to those of the only other study on associated genera of pollinating and nonpollinating fig wasps (62.5\%), by Machado et al . (1996). The partial concordance of Pleistodontes and Sycoscapter phylogenies may be mediated through their common use of Malvanthera fig plants, rather than through their own direct interaction, with the sequential radiation of Sycoscapter across Malvanthera species following a pattern broadly similar to that of the radiation of Pleistodontes. For this reason, we urgently need a robust phylogeny for the Malvanthera to compare with the phylogenies of both wasp genera. We also need a better understanding of the larval ecology of Sycoscapter (and indeed other nonpollinating wasp) species. Are they parasitoids that feed directly on wasps (pollinators and/or other nonpollinators) or kleptoparasites reliant upon Pleistodontes to initiate galls that produce plant material on which both wasp taxa feed? Studies of other sycoryctine fig wasps favor the latter case (Abdurahiman and J oseph, 1978a,b) but hardly constitute conclusive evidence.

Among the possible explanations for incongruence between Sycoscapter and Pleistodontes phylogenies, perhaps the most interesting is host plant switching by either group. Some aspects of host plant biology (e.g., geographic distribution) apply to both groups of wasps, but others influence one group but not the other. For example, Pleistodontes females enter the fig inflorescence through a narrow tunnel (the ostiole) to reproduce, whereas Sycoscapter females use their long ovipositors to lay eggs through the wall of the inflorescence without entering it. Since morphological features of pollinating wasps (especially head shape) appear to be highly adapted for entering their host fig (Van Noort and Compton 1996), physical barriers to host shifting are more likely to apply to pollinators.

Another important factor is chemical signaling by figs. Pollinating wasps rely heavily on chemical cues to locate receptive figs. Recent studies have shown that they respond to the ratios of a few plant volatiles and suggest that chemistry may play an important role in host specificity (M. Hossaert-McKey, pers. comm.). To date, nobody has investigated host plant location by nonpollinating wasps. However, we do know that Sycoscapter wasps lay eggs into relatively mature Malvanthera figs, some weeks after they have been pollinated (J .M.C., pers. obs.). The chemical signals of older figs are likely to be different from those of receptive figs, perhaps increasing the probability of "mistakes" by nonpollinating wasps. F urthermore, whereas selection on figs favors attraction of the specific pollinators

TABLE 7

Results of the Treemap Cospeciation Analysis Using Different Datasets

\begin{tabular}{lccccccc}
\hline Pleistodontes tree & Sycoscapter tree & No. of taxa & Max. & Cosp & $\%$ & Observed P value & Corrected P value \\
\hline 28S + Cyt b ML & 28S + Cyt b ML & 13 & 12 & 6 & 50 & 0.082 & 0.225 \\
28S + ITS2 ML & 28S + Cyt b ML & 15 & 14 & 8 & 57.14 & $\mathbf{0 . 0 1 1}$ & 0.055 \\
28S + ITS2 MP & 28S + Cyt b ML & 15 & 14 & 9 & 64.28 & $\mathbf{0 . 0 0 1}$ & $\mathbf{0 . 0 0 8}$ \\
\hline
\end{tabular}

Note Max, the maximum possible number of cospeciation events; Cosp, the number of cospeciation events observed; \%, the percentage of cospeciating nodes detected ( $\%=100 \times$ Cosp/Max); P value, the "corrected" P values (see text) obtained by randomization of both trees 1000 times with the proportional-to-distinguishable model. The significant results $(P \leq 0.05)$ are highlighted in boldface. 


\section{Pleistodontes \\ MP 28S rRNA + ITS2}

\section{Sycoscapter}

28S rDNA + Cyt $b$

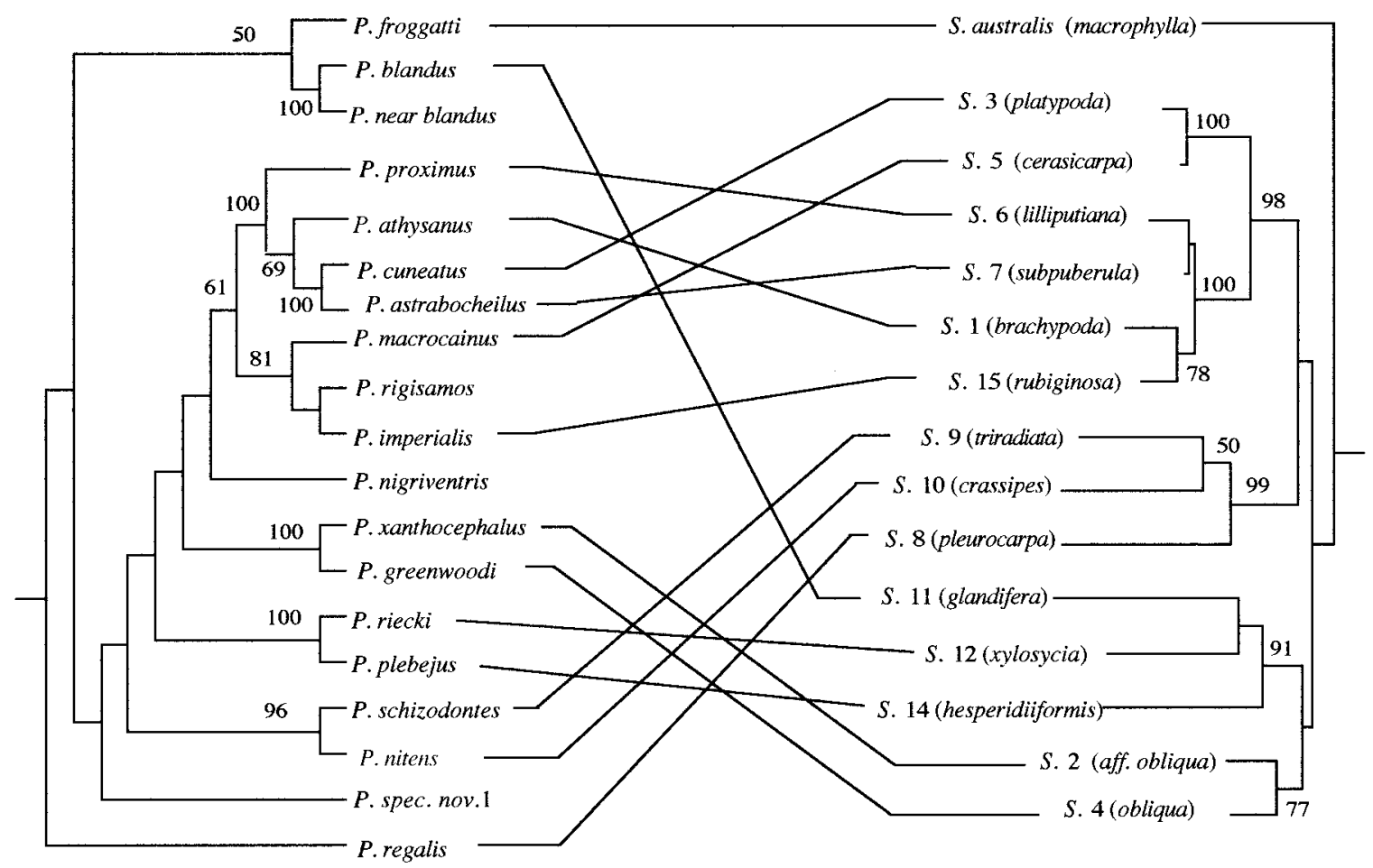

FIG. 6. Phylogenies for Pleistodontes and their associated Sycoscapter species drawn as cladogram and phylogram, respectively. The Pleistodontes MP tree is based on partial sequences of 28S + Cyt b; the Sycoscapter ML tree is based on 28S + ITS2. Lines connect pollinating wasps with their specific associated nonpollinating wasps. Numbers on branches are bootstrap values for parsimony searches.

to receptive fruits, it should oppose attraction of nonpollinating wasps to more mature figs.

As more studies are carried out on the phylogenies of fig wasp communities, we will discover which taxa have high degrees of cospeciation and should be able to relate variation in cospeciation levels to biological features of species interactions. One possibility is that nonpollinating wasps that lay eggs in relatively mature fig fruits may host shift more frequently than those that oviposit in receptive or recently pollinated fig fruits, as a result of the chemical signals available.

\section{Methodological I ssues}

Methods of reconstructing the history of association between hosts and parasites such as the one used in this paper, maximum cospeciation analysis (Page, 1995), and others (Brooks, 1981; Ronquist, 1996, 1998; Charleston, 1998) have been criticized recently for the assumption that host and parasite phylogenies are estimated without error (Huelsenbeck et al., 2000; J ohnson et al., 2001). I ndeed, the level of support for cospeciating nodes is not taken into account when tree topologies are simply compared (Clark et al., 2000). Huelsenbeck et al. (2000) proposed a new method based on a stochastic model of host switching that used
Bayesian inference, which allows estimation of the host switching rate, without assuming that the phylogeny is error-free. In other words, the DNA sequences, rather than the topologies, are compared.

Support for cospeciating nodes is an important issue, which we return to bel ow; however, no method is errorfree, given that models of DNA substitution may be oversimplified (Posada and Crandall, 1998), and errors can be made in sampling or character scoring. In addition, the approach of Huelsenbeck et al. (2000) has other limitations, such as assuming that host switching is the only cause of incongruence between phylogenies.

The absence of perfect concordance between phylogenies can result from differences in data quality (Clark et al., 2000), as illustrated by our suboptimal 285 + Cyt b phylogeny (Fig. 2), which reduces the estimate of cospeciation to borderline significance. The availability of a general "cospeciation index" to compare between studies is highly desirable and, to date, the maximum percentage of cospeciating nodes (as estimated by Treemap) is the only one to have been advocated (Taylor and Purvis, 2001). Unfortunately, in itself, this value may not tell us a great deal, and this is illustrated by 


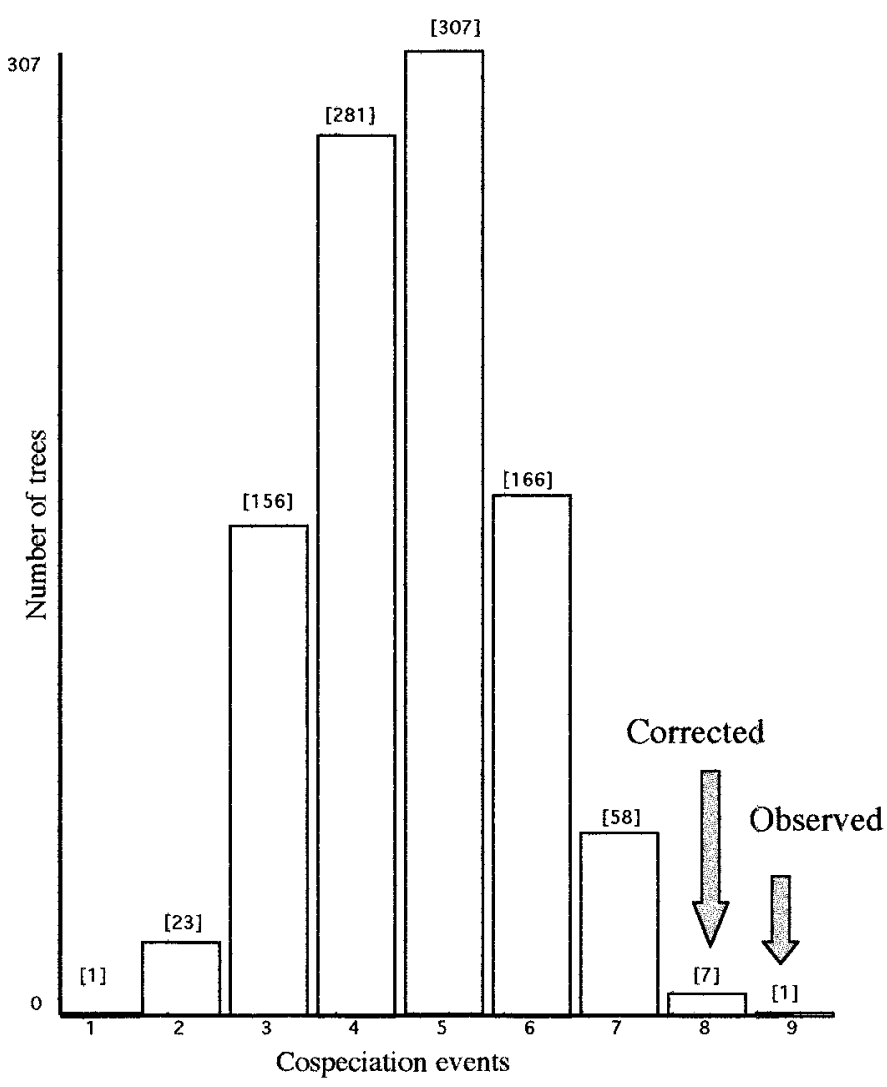

FIG. 7. Distribution of the maximum number of cospeciation events inferred from 1000 randomizations of the Pleistodontes and Sycoscapter trees generated by the proportional-to-distinguishable model. Arrows show the observed (9) estimates of the maximum number of cospeciation events and a conservative corrected estimate (8).

contrasting our study with that of Clark et al. (2000). Their overall findings are consistent with a history of strict cospeciation of aphids and endosymbionts. In fact, surprisingly, congruence among different aphid mitochondrial genes was no greater than that between aphid and symbiont genes (Clark et al., 2000). However, the overall percentage of cospeciation was estimated at only 50-56.3\%. In contrast, in our study, there is strong evidence for incongruence (ILD and SH tests) between pollinator and parasite phylogenies and yet the estimate of cospeciation is about the same (50$64 \%$ ). Thus, both the distribution of, and the support for, may be as important as the overall percentage of cospeciating nodes.

In our study, genes in the same organisms were generally congruent (except Cyt b and ITS2 in Pleistodontes) but phylogenies of pollinators and parasites were incongruent. However, this does not necessarily mean that cospeciation is uncommon, since a small number of host switches in well-resolved trees can result in incongruence. In addition, recent studies have emphasized that the ILD is not an ideal test of whether two data sets support the same underlying topology because the test result is also influenced by the rate of evolution and the level of homoplasy. If one of the data sets (such the Pleistodontes Cyt b data set) is noisier than the other, this could result in a spurious significant result due to noise alone (Dolphin et al., 2000). However if a nonsignificant result is obtained (in our case only between data sets from the same organism), it is probably safe to say that the data sets are congruent. On the other hand, the SH test and other likelihood-based tests of topol ogies, such as parametric bootstrapping (Huelsenbeck et al., 1996b), seem appropriate for testing the null hypothesis that molecular data collected for Pleistodontes and Sycoscapter are consistent with the same underlying phylogeny, since these tests compare all members of a given set of a priori possible topologies (Goldman et. al., 2000). Nevertheless, the results of Clark et al. (2000) suggest that some maximum-likelihood-based tests (they used $\mathrm{KH}$ and likelihood ratio tests) may reject the null hypothesis of perfect matching even if it is true, especially if the number of taxa is fairly large. They also suggest that having multiple genes from the same taxon, especially from nonrecombining mitochondrial regions, is one way to assess whether random matching is being falsely rejected. A related point is that, as the number of taxa increases, it becomes extremely unlikely that even an exceptionally well-planned and intensive study will actually generate the two "true" trees, so significant incongruence may generally increase with the number of taxa considered.

These methodological issues will clearly require further development and debate as more and larger phylogenies of interacting taxa become available for comparison. However, for now, we conclude that the partial matching of phylogenies showed by Treemap analysis and the significant levels of incongruence revealed by both SH and ILD tests support a history of significant but incomplete cocladogenesis between Pleistodontes and Sycoscapter wasps. Furthermore, their independent transmission processes and nonidentical phylogenies suggest a likely role for host switching in the evolutionary history of this association.

\section{Molecular and Morphological Evolution}

Dramatic examples of the "uncoupling" of rates of molecular and morphological evolution are found in several lineages, including African cichlid fishes (Sturmbauer and Meyer, 1992), Pacific scincid lizards (Bruna et al., 1996), and horseshoe crabs (Selander et al., 1970). Whereas Pleistodontes species display considerable morphological differentiation (C. Lopez-Vaamonde et al.,unpublished), Sycoscapter species (especially the females) are extremely similar in appearance (unpublished data). Although the differences in rates of molecular divergence are less dramatic, it is nevertheless Sycoscapter that shows the greater divergence (t test 
results), suggesting that molecular and morphological evolution are not tightly coupled.

The greater genetic distances between Sycoscapter species than between their associated pollinators suggest that Sycoscapter may have the higher rate of molecular evolution. Another possibility is that Sycoscapter species are older. However, since all Malvanthera figs are pollinated by Pleistodontes species, and these two clades have presumably radiated over the same time scale, this would require that many of the Sycoscapter species originated on other fig species (not Malvanthera) and subsequently underwent host shifts. Such a scenario seems unlikely, given evidence for significant levels of cospeciation between Malvantheraassociated Pleistodontes and Sycoscapter species.

We must be cautious in our interpretation of relative rates of evolution since our use of the test assumes that all pairwise distances are independent. Clearly they are not since each species is used several times and tree structure is ignored. However, these tests give us a crude index in the absence of fully congruent pollinator and parasite clades for formal comparison (see Hafner and Nadler, 1990). In addition, we can compare the $28 \mathrm{~S} \mathrm{ML}$ branch lengths for the two pairs of potentially cospeciated terminal sister taxa (i.e., P. xanthocephalus/S.2 + P. greenwoodi/S.4 and P. schizodontes/S.9 + P. nitens/S.10). The branch lengths were quite similar in both cases $(0.010 / 0.016$ and $0.005 /$ 0.006 for the first pair and $0.009 / 0.012$ and $0.013 / 0.003$ for the second pair), with the parasite having the longer branch in three cases and the pollinator in one (but this one had a larger difference). These data are far from conclusive but, for the moment, we conclude that the t tests and limited branch length comparisons suggest that there are not consistent major differences in genetic distances between species in the two genera.

We can also turn the question around and ask why females of different Pleistodontes species clearly show much greater morphological differentiation than females of the associated Sycoscapter species. There is an obvious (but unproven) answer to this question, which concerns their respective interactions with the fig inflorescence (syconia). The female pollinating wasps must enter the syconia of their host figs, and this involves adaptation to the anatomical structure of the fig and especially to the task of entering it via the tight and narrow ostiolar tunnel. The influence of syconium anatomy on wasp head morphology has been demonstrated by analysis of the parallel morphological adaptations of pairs of African pollinator wasp species and their associated members of an unusual clade of (sycoecine) fig-parasitic wasps that also enter the fig fruits (Van Noort and Compton 1996). We expect a high degree of coadaptation of the morphol ogy of Pleistodontes females and their host fig syconia. In contrast, Sycoscapter females oviposit only through the fig wall and seem more likely to respond to syconial evolution largely in terms of their ovipositor length and form. Given that the mean diameters of ripe Malvanthera syconia vary from about $0.5 \mathrm{~cm}$ ( $F$. obliqua) to over 5 $\mathrm{cm}$ ( $F$. sterrocarpa), and in shape from spherical to elongate cylindrical with an extended ostiole, there is great scope for coadaptation of pollinator morphology in this group. In contrast, Sycoscapter species are also known from a wide range of non-Malvanthera fig species in Asia and Africa, and the female wasps generally show rather limited morphological variation.

\section{CONCLUSION}

The intimate invertebrate communities found within fig syconia provide excellent models for the study of cospeciation and host switching. Each Ficus species is typically host to one pollinating and many different nonpollinating wasp species (from different genera), in addition to mites and nematodes (Herre, 1996). Exploration of the phylogenetic relationships within and between these different groups, in tandem with studies of their trophic ecology, should help us better understand the interplay between ecology and cospeciation. One cannot overemphasize the importance of good alpha taxonomy to underpin cospeciation studies, and the Malvanthera (Dixon, 2001a,b; Dixon et al., 2001) and Pleistodontes (C. Lopez-Vaamonde et al ., unpublished) are the only fig section and corresponding pollinating wasp genus to be subjected to recent, intensive, taxonomic revision.

Our study shows significant but imperfect correspondence between the phylogenies of associated pollinating and nonpollinating fig wasp genera. At present we cannot be sure whether this is due to their direct interaction or whether it is mediated through other processes (e.g., resource tracking of figs) leading to partial phylogenetic congruence. Consequently, there is an urgent need to generate a phylogeny of the Malvanthera figs for comparison with both wasp phylogenies. Additional data on the ecology and taxonomy of the nonpollinating wasps will also be important to our understanding, and morphological studies of Malvanthera fig syconia and the wasps that inhabit them will soon permit tests of ideas about the morphological coadaptation of these interacting taxa.

\section{ACKNOWLEDGMENTS}

We thank Dale Dixon, Brus Isua, J ohn Lattke, and J ohn Zammit for providing wasp specimens, and Elisabeth Herniou, Sally Power, Hugh Spencer, Sampson Laup, and Luc Leblanc for fieldwork assistance. Earlier manuscripts were much improved by Robert Belshaw, J ason Taylor, Salvador Carranza, Kevin J ohnson, Carole Kerdel hue, Elisabeth Herniou, and two anonymous reviewers. We are grateful to Frank Van Veen for providing ITS2 primer sequences. Special thanks must go to Andrew Rambaut, Konrad Dol phin, David Posada, and J oseph Thorley for advice on the use of SHTest, ILD test, Modeltest, and Radcon, respectively, and to Anthony Cognato for 
comments on the cyt b saturation analysis. Financial support was provided by a British Council/Fundacion Barrie de la Maza postgraduate grant to C.L.V and a NERC Advanced Fellowship to J.M.C. Fieldwork was partly funded by a British Ecological Society Small Project Grant ( .M.C) and a European Science Foundation (Canopy Tropical Research) travel grant (C.L.V).

\section{REFERENCES}

Abdurahiman, U. C., and J oseph, K. J . (1978a). Biology and behaviour of Apocrypta bakeri J oseph (Torymidae), cleptoparasite of Ceratosolen marchali Mayr (Agaonidae). Entomon 3: 31-36.

Abdurahiman, U. C., and J oseph, K. J . (1978b). Cleptoparasitism of the fig wasps (Torymidae: Chalcidoidea) in Ficus hispida. Entomon 3: 181-186.

Akaike, H. (1974). A new look at the statistical model identification. IEEE Trans. Autom. Contr. 19: 716-723.

Anstett, M. C., Hossaert MacKey, M., and Kjellberg, F. (1997). Figs and fig pollinators: Evolutionary conflicts in a coevolved mutualism. Trends Ecol. Evol. 12: 94-99.

Boucek, Z. (1988). Family Agaonidae. In "Australian Chalcidoidea (Hymenoptera): A Biosystematic Revision of Genera and Fourteen Families, with a Reclassification of Species," pp. 156-209. CAB International, Wallingford, UK.

Boucek, Z. (1993). The genera of Chalcidoidea wasps from Ficus fruit in the New World. J. Nat. Hist. 27: 173-217.

Brooks, D. R. (1981). Hennig's parasitological method: A proposed solution. Syst. Zool. 30: 229-249.

Bruna, E. M., Fisher, R. N., and Case, T. J . (1996). Morphological and genetic evolution appear decoupled in Pacific skinks (Squamata: Scincidae: Emoia). Proc. R. Soc. Lond. B. 263: 681- 688.

Buckler, E. S., I ppolito, A., and Holtsford, T. P. (1997). The evolution of ribosomal DNA: Divergent paralogues and phylogenetic implications. Genetics 145: 821-832.

Bull, J . J ., Huelsenbeck, J . P., Cunningham, C. W., Swoford, D. L., and Waddell, P. J. (1993). Partitioning and combining data in phylogenetic analysis. Syst. Biol. 42: 384-397.

Campbell, B. C., Steffen-Campbell, J . D., and Werren, J. H. (1993). Phylogeny of the Nasonia complex (Hymenoptera: Pteromalidae) inferred from an internal transcribed spacer (ITS2) and 28S rDNA sequences. Insect Mol. Biol. 2: 225-237.

Charleston, M. A. (1998). J ungles: A new solution to the host/parasite phylogeny reconciliation problem. Math. Biosci. 149: 191-223.

Clark, M. A., Moran, N. A., Baumann, P., and Wernegreen, J . J . (2000). Cospeciation between bacterial endosymbionts (Buchnera) and a recent radiation of aphids (Uroleucon) and pitfalls of testing for phylogenetic congruence. Evolution 54: 517-525.

Clayton, D. H., Al-Tamimi, S., and J ohnson, K. P. (2001). The ecological basis of coevolutionary history. In "Tangled Trees: Phylogeny, Cospeciation and Coevolution" (R.D.M. Page, Ed.). Univ. of Chicago Press, Chicago, in press.

Cook, J . M., and Power, S. A. (1996). Effects of within-tree flowering asynchrony on the dynamics of seed and wasp production in an Australian fig species. J . Biogeogr. 23: 487- 493.

Compton, S. G., Rasplus, J . Y., and Ware, A. B. (1994). African fig wasp parasitoid communities. In "Parasitoid Community E cology" B. A. Hawkins and W. Sheehan, Eds.), pp. 343-370. Oxford Univ. Press, Oxford.

Corner, E. J . H. (1965). Check list of Ficus in Asia and Australasia with key of identification. Gard. Bull. Sing. 21: 1-186.

Cunningham, C. W. (1997). Can three incongruence tests predict when data should be combined? Mol. Biol. Evol. 14: 733-740.

Demastes, J. W, Hafner, M. S., Hafner, D. J ., and Spradling, T. A.
(1998). Pocket gophers and chewing lice: A test of the maternal transmission hypothesis. Mol. Ecol. 7: 1065-1069.

Dixon, D. J . (2001a). Ficus Iilliputiana (Moraceae), a new species from the Kimberley region of Western Australia and the Northern Territory. Nuytsia 13: 457- 464.

Dixon, D. J . (2001b). Figs, wasps, and species concepts: A re-evaluation of the infraspecific taxa of Ficus macrophylla (Moraceae: U rostigma sect. Malvanthera). Aust. Syst. Bot. 14: 125-132.

Dixon, D. J ., J ackes, B. R., and Bielig, L. M. (2001). Figuring out the figs: The Ficus obliqua-Ficus rubiginosa complex (Moraceae: Urostigma sect. Malvanthera). Aust. Syst. Bot. 14: 133-154.

Dolphin, K., Belshaw, R., Orme, C. D. L., and Quicke, D. L. J . (2000). Noise and incongruence: I nterpreting results of the Incongruence Length Difference test. Mol. Phylogenet. Evol. 17: 401- 406.

Ehrlich, P. R., and Raven, P. H. (1964). Butterflies and plants: A study in coevolution. Evolution 18: 586- 608.

Farrell, B., and Mitter, C. (1990). Phylogenesis of insect/plant interactions: Have Phyllobrotica and the Lamiales diversified in parallel? Evolution 44: 1389-1403.

Farrell, B., and Mitter, C. (1998). The timing of insect/plant diversification: Might Tetraopes (Coleoptera: Cerambycidae) and Asclepias (Asclepiadaceae) have coevolved? Biol. J . Linn. Soc. 63: 553577.

Farris, J . S. (1970). Methods for computing Wagner trees. Syst. Zool . 18: 374-385.

Felsenstein, J . (1981). Evolutionary trees from DNA sequences: A maximum likelihood approach. J . Mol. Evol. 17: 368-376.

Felsenstein, J . (1985). Confidence limits on phylogenies: An approach using the bootstrap. Evolution 39: 783-791.

Funk, D. J ., Helbling, L., Wernegreen, J . J ., and Moran, N. (2000). Intraspecific phylogenetic congruence among multiple symbiont genomes. Proc. R. Soc. Lond. B 267: 2517-2521.

Goldman, N., Anderson, J . P., and Rodrigo, A. G. (2000). Likelihoodbased tests of topologies in phylogenetics. Syst. Biol . 49: 652- 670.

Hafner, M. S., and Nadler, S. A. (1988). Phylogenetic trees support the coevolution of parasites and their hosts. Nature 332: 258-259.

Hafner, M. S., and Nadler, S. A. (1990). Cospeciation in host-parasite assemblages: Comparative analysis of rates of evolution and timing of cospeciation events. Syst. Zool. 39: 192-204.

Hafner, M. S., and Page, R. D. M. (1995). Molecular phylogenies and host-parasite cospeciation: Gophers and lice as a model system. Phil. Trans. R. Soc. Lond. B 349: 77- 83.

Hafner, M. S., Sudaman, P. D., Villablanca, F. X., Spradling, T. A., Demastes, J. W., and Nadler, S. A. (1994). Disparate rates of molecular evolution in cospeciating parasites and hosts. Science 265: 1087-1090.

Harris, D. J., and Crandall, K. A. (2000). Intragenomic variation within ITS1 and ITS2 of freshwater crayfishes (Decapoda: Cambaridae): I mplications for phylogenetic and microsatellite studies. Mol. Biol. Evol. 17: 284-291.

Harry, M., Solignac, M., and Lachaise, D. (1996). Adaptive radiation in the Afrotropical region of the Paleotropical genus Lissocephala (Drosophilidae) on the pantropical genus Ficus (Moraceae). J . Biogeogr. 23: 543-552.

Hendy, M. D., and Penny, D. (1982). Branch and bound algorithms to determine minimal evolutionary trees. Math. Biosci. 59: 277-290.

Herre, E. A. (1989). Coevolution of reproductive characteristics in 12 species of new world figs and their pollinator wasps. Experientia 45: 637- 647.

Herre, E. A. (1996). An overview of studies on a community of Panamanian figs. J . Biogeogr. 23: 593- 607.

Herre, E. A., Machado, C. A., Bermingham, E., Nason, J . D., Windsor, D. M., McCafferty, S. S., VanHouten, W., and Bachmann, K. 
(1996). Molecular phylogenies of figs and their pollinator wasps. J . Biogeogr. 23: 521-530.

Higgins, D. G., and Sharp, P. M. (1988). CLUSTAL: A package for performing multiple sequence alignment on a microcomputer. Gene 73: 237-244.

Huelsenbeck, J. P., (1991). Tree-length skewness: An indicator of phylogenetic information. Syst. Zool. 40: 257-270.

Huelsenbeck, J. P., Bull, J. J ., and Cunningham, C. W. (1996a). Combining data in phylogenetic analysis. Trends Ecol. Evol. 11: 152-158.

Huelsenbeck, J . P., Hillis, D. M., and J ones, R. (1996b). Parametric bootstrapping in molecular phylogenetics: Applications and performance. In "Molecular Zoology: Advances in Strategies and Protocols" (J . D. Ferraris and S. R. Palumbi, Eds.), pp. 19-45. WileyLiss, New York.

Huelsenbeck, J . P., Rannala, B., and Yang, Z. H. (1997). Statistical tests of host-parasite cospeciation. Evolution 51: 410- 419.

Huelsenbeck, J. P., Rannala, B., and Larget, B. (2000). A Bayesian framework for the analysis of cospeciation. Evolution 54: 352-364.

Huelsenbeck, J . P., Rannala, B., and Larget, B. (2001). A statistical perspective for reconstructing the history of host-parasite associations. In "Tangled Trees: Phylogeny, Cospeciation and Coevolution" (R. D. M. Page, Ed.), Univ. of Chicago Press, Chicago, in press.

Hugo, J. P. (1999). Primates and their pinworms parasites: The Cameron hypothesis revisited. Syst. Biol. 48: 523-546.

J ermiin, L. S., and Crozier, R. H., (1994). The cytochrome-b region in the mitochondrial DNA of the ant Tetraponera rufoniger-Sequence divergence in Hymenoptera may be associated with nucleotide content. J . Mol. Evol. 38: 282-294.

J ermy, T. (1976). Insect host-plant relationship-Co-evolution or sequential evolution? In "The Host-plant in relation to insect behaviour and reproduction" (T. J ermy Ed.), pp. 109-113. Plenum, New York.

J ohnson, K. P., and Clayton, D. H. (2001). Coevolutionary history of ecological replicates: Comparing phylogenies of wing and body lice to Col umbiform hosts. In "Tangled Trees: Phylogeny, Cospeciation and Coevolution" (R. D. M. Page, Ed.). Univ. of Chicago Press, Chicago, in press.

J ohnson, K. P., Drown, D. M., and Clayton, D. H. (2001). A data based parsimony method of cophylogenetic analysis. Zool. Scripta, 30: $79-87$.

Kerdelhue, C., Le Clainche, I., and Rasplus, J. Y. (1999). Molecular phylogeny of the Ceratosolen species pollinating Ficus of the subgenus Sycomorus sensu stricto: Biogeographical history and origins of the species-specificity breakdown cases. Mol. Phylogenet. Evol. 11: 401-414.

Kethley, J . B., and J ohnston, D. E. (1975). Resource tracking patterns in bird and mammal ectoparasites. Misc. Publ. Entomol. Soc. Am. 9: 231-236.

Lyal, C. H. C. (1986). Coevolutionary relationships and their hosts: A test of Farenholz's rule. In "Coevolution and Systematics" (A. R. Stone and D. L. Hawksworth, Eds.), pp. 77-91. Syst. Assoc., Clarendon, Oxford.

Machado, C. A., Herre, E. A., McCafferty, S., and Bermingham, E. (1996). Molecular phylogenies of fig pollinating and non-pollinating wasps and the implications for the origin and evolution of the fig-fig wasp mutualism. J . Biogeogr. 23: 531-542.

Machado, C. A., J ousselin, E., Kjellberg, F., Compton, S. G., and Herre, E. A. (2001). Phylogenetic relationships, historical biogeography and character evolution of fig-pollinating wasps. Proc. R. Soc. Lond. B 268: 1-10.

Madison, D. R., and Madison, W. P. (2000). MacClade 4.0. Sinauer, Sunderland, MA.
Martin, J ., Herniou, E., Cook, J ., Waugh O'N eill, R., and Tristem, M. (1999). Interclass transmission and phyletic host tracking in $\mathrm{Mu}$ rine Leukemia virus-related retroviruses. J . Virol. 73: 2442-2449.

Moran, N. A., Von Dohlen, C. D., and Baumann, P. (1995). Faster evolutionary rates in endosymbiotic bacteria than in cospeciating insect hosts. J. Mol. Evol. 41: 727-731.

Nadler, S. A., Hafner, M. S., Hafner, J . C., and Hafner, D. J . (1990). Genetic differentiation among chewing louse populations (Mallophaga: Trichodectidae) in a pocket gopher contact zone (Rodentia: Geomyidae). Evolution 44: 942-951.

Page, R. D. M. (1990). Temporal congruence and cladistic analysis of biogeography and cospeciation. Syst. Zool. 39: 205-226.

Page, R. D. M. (1993a). Parasites, phylogeny and cospeciation. Int. J . Parasitol. 23: 499-506.

Page, R. D. M. (1993b). Genes, organisms and areas: The problem of multiple lineages. Syst. Biol. 42: 77- 84.

Page, R. D. M. (1994). Parallel phylogenies: Reconstructing the history of host-parasite assemblages. Cladistics 10: 155-173.

Page, R. D. M. (1995). TREEMAP program. Availability: http:// taxonomy.zoology.gla.ac.uk/rod/treemap.html.

Page, R. D. M. (1996a). Temporal congruence revisited: Comparison of mitochondrial DNA sequence divergence in cospeciating pocket gophers and their chewing lice. Syst. Biol. 45: 151-167.

Page, R. D. M. (1996b). Lice and cospeciation: A response to Barker. Int. J . Parasitol. 26: 213-218.

Page, R. D. M., and Charleston, M. A. (1998). Trees within trees: Phylogeny and historical associations: Trends Ecol. Evol. 13: 356359.

Paterson, A. M., Wallis, G. P., Wallis, L. J ., and Gray, R. D. (2000). Seabird and louse coevolution: Complex histories revealed by 125 rRNA sequences and reconciliation analyses. Syst. Biol. 49: 383399.

Peek, A. S., Feldman, R. A., Lutz, R. A., and Vrijenhoek, R. C. (1998). Cospeciation of chemoautotrophic bacteria and deep sea clams. Proc. Natl. Acad. Sci. USA 95: 9962-9966.

Pellmyr, O., and Leebens-Mack, J . (1999). Forty million years of mutualism: Evidence for Eocene origin of the yucca moth association Proc. Natl. Acad. Sci. USA 96: 9178-9183.

Poinar, G. O., J r., and Herre, E. A. (1991). Speciation and adaptive radiation in the fig wasp nematode. Paraditodi plogaster (Diplogasteridae: Rhabditida), in Panama. Rev. Nematol. 14: 361-374.

Posada, D., and Crandall, K. A. (1998). Modeltest: Testing the model of DNA substitution. Bioinformatics. 14: 817-818.

Price, P. W. (1977). General concepts on the evolutionary biology of parasites. Evolution 31: 403- 420.

Rambaut, A. (2000). SHTests v1.0. Shimodaira and Hasegawa Tests of Phylogenetic Hypotheses. Program availability: http://evolve. zoo.ox.ac.uk/software/shtests.

Ramirez, B. W. (1974). Co-evolution of Ficus and Agaonidae. Ann. Miss. Bot. Gard. 61: 770-780.

Ramirez, B. W. (1977). A new classification of Ficus. Ann. Miss. Bot. Gard. 64: 296-310.

Rasplus, J . Y, Kerdelhue, C., le Clainche, I., and Mondor, G. (1998). Molecular phylogeny of fig wasps: Agaonidae are not monophyletic. C. R. Acad. Sci. 321: 517-527.

Rodriguez, F., Oliver, J . L., Marin, A., and Medina, J . R. (1990). The general stochastic model of nucleotide substitution. J . Theor. Biol. 142: 485-501.

Ronquist, F. (1996). Reconstructing the history of host-parasite association using generalised parsimony. Cladistics 11: 73- 89.

Ronquist, F. (1998). Phylogenetic approaches in coevolution and biogeography. Zool. Scripta 26: 313-322.

Selander, R. K., Yang, S. Y., Lewontin, R. C., and J ohnson, W. E. 
(1970). Genetic variation in the horseshoe crab (Limulus polyphemus), a phylogenetic "relict". Evolution 24: 402- 414.

Shimodaira, H., and Hasegawa, M. (1999). Multiple comparsions of log-likelihoods with applications to phylogenetic inference. Mol. Biol. Evol. 16: 114-116.

Singer-Sam, J ., Tanguay, R., C., and Riggs, A., D. (1989). Use of Chelex to improve the PCR signal from a small number of cells. Amplifications 3: 11.

Stone, G. N., and Cook, J . M. (1998). The structure of cynipid oak galls: Patterns in the evolution of an extended phenotype. Proc. R. Soc. Lond. B 265: 979-988.

Sturmbauer, C., and Meyer, A. (1992). Genetic divergence, speciation and morphological stasis in a lineage of African cichlid fishes. Nature 358: 578-581.

Swofford, D. L. (1999). PAUP*: Phylogenetic analysis using parsimony (*and other methods), version 4.0. Sinauer, Sunderland, MA.

Tamura, K., and Nei, M. (1993). Estimation of the number of nucleotide substitutions in the control region of mitochondrial DNA in humans and chimpanzees. Mol. Biol. Evol. 10: 512-526.

Taylor, J ., and Purvis, A. (2001). Have mammals and their chewing lice diversified in parallel? In "Tangled Trees: Phylogeny, Cospeciation and Coevolution" (R. D. M. Page, Ed.), Univ. of Chicago Press, Chicago, in press.
Thorley, J. L., and Page, R. D. M. (1999). RadCon0.7. program. Availability: http://taxonomy.zoology.gla.ac.uk/-jthorley/.

Thorley, J . L., and Wilkinson, M. (1999). Testing the phylogenetic stability of early tetrapods J. Theor. Biol. 200: 343-344.

Van Noort, S., and Compton, S. G. (1996). Convergent evolution of agaonine and sycoecine (Agaonidae, Chalcidoidea) head shape in response to the constraints of host fig morphology. J . Biogeogr. 23: 415- 424.

Weiblen, G. D. (2000). Phylogenetic relationships of functionally dioecious Ficus (Moraceae) based on ribosomal DNA sequences and morphology. Am. J . Bot. 87: 1342-1357.

Wesson, D. M., Porter, C. H., and Collins, F. H. (1992). Sequence and secondary structure comparisons of ITS rDNA in mosquitoes (Diptera: Culicidae). Mol. Phylogenet. Evol. 1: 253-269.

West, S. A., Cook, J. M., Werren, J. H., and Godfray, H.C.J . (1998). Wol bachia in two insect host-parasitoid communities. Mol. E col. 7: 1457-1465.

Wiebes, J. T. (1982a). Fig wasps (Hymenoptera). In "Biogeography and Ecology of New Guinea" (J. L. Gressit, Ed.), pp. 735-755. Monographiae Biologicae, 42.

Wiebes, J. T. (1982b). The phylogeny of the Agaonidae (Hymenoptera, Chalcidoidea). Neth. J . Zool. 32: 395- 411.

Yang, Z., Goldman, N., and Friday, A. (1994). Estimating the pattern of nucleotide substitution. J . Mol. Evol. 39: 105-111. 